Estudios sobre armas antiguas, arte militar $\mathrm{y}$ vida cultural en oriente y occidente XXXVII (2017), pp. 69-108

ISSN: 0436-029X doi: 10.3989/gladius.2017.03

\title{
LAS ESPADAS DE LA NECRÓPOLIS DE EL CASTILLO (CASTEJÓN, NAVARRA)
}

\author{
SWORDS FROM THE NECROPOLIS OF EL CASTILLO \\ (CASTEJÓN, NAVARRA)
}

POR

José Antonio Faro CARballa*

\section{RESUMEN - ABSTRACT}

Este artículo tiene por objeto estudiar las espadas halladas en la necrópolis de El Castillo (Castejón, Navarra). Proceden de tumbas fechadas en la Segunda Edad del Hierro, entre la $2^{\mathrm{a}} 1 / 2 \mathrm{del}$ s. IV y el s. III a. C. Un período marcado por un proceso de generalización del armamento y por la existencia de enterramientos con panoplias complejas, con armas tanto ofensivas como defensivas. La singularidad del yacimiento se ve reflejada en el conjunto analizado, en el que se documentan tres modelos muy diferentes de espadas.

This paper aims to study the swords discovered in the necropolis of El Castillo (Castejón, Navarra). They come from tombs dated in the Second Iron Age, between the 2 nd $1 / 2$ of 4 th c. and $3 \mathrm{rd} \mathrm{c}$. BC. A period marked by a process of generalization of armament and by the existence of burials with complex panoplies, with both offensive and defensive weapons. The uniqueness of the site is reflected in the analyzed set, in which three very different models of swords are documented.

\section{Palabras Clave - Keywords}

Necrópolis de El Castillo; valle medio del Ebro; Segunda Edad del Hierro; espadas.

Necropolis of El Castillo; Middle Ebro valley; Second Iron Age; swords.

\section{Cómo CITAR este ARtículo / Citation}

Faro Carballa, J. A. (2017): «Las espadas de la necrópolis de El Castillo (Castejón, Navarra)». Gladius, XXXVII: 69-108. doi: 10.3989/gladius.2017.03

\section{INTRODUCCIÓN}

La inmensa mayoría de las armas documentadas en el territorio ibérico y celtibérico proceden de contextos cultuales, principalmente de necrópolis, depósitos rituales y santuarios. Esta estadística es un fiel reflejo de la trascendencia de estos objetos, que va más allá de su valor intrínseco como instrumentos diseñados para el combate y que radica en sus múltiples connotaciones tanto simbólicas como de tipo económico, político, social o religioso.

*UNED, j.antoniofaro@gmail.com / ORCID iD: http://orcid.org/0000-0003-1203-3734. 
La aparición de sociedades guerreras en la península ibérica se remonta a la cultura campaniforme, a finales del III milenio a. C. En el Centro y en el Occidente, a lo largo de toda la Edad del Bronce y comienzos de la Edad del Hierro, los modos de vida y la necesidad de garantizar la defensa de los recursos económicos favorecieron el desarrollo de comunidades en las que los guerreros gozaron de un estatus privilegiado. Aunque, como señala M. Almagro-Gorbea, fue a finales del s. VI a. C., coincidiendo con la decadencia de Tartessos y el final del período orientalizante, cuando se produjo una profunda transformación en todos los territorios peninsulares que afectó a la organización social y también al concepto de guerra. Las nuevas élites aristocráticas que asumieron el control del poder tenían un carácter gentilicio, fundado en la pertenencia a un grupo descendiente de un antepasado mítico común, real o imaginario, y de índole esencialmente guerrera (Almagro-Gorbea, 1997: 208-216). Las armas se convirtieron en marcadores políticos y sociales, en demostraciones de jerarquía. Los guerreros comenzaron a incinerarse con sus panoplias y las armas, que hasta entonces únicamente habían tenido una presencia esporádica y excepcional en los enterramientos, adquirieron un papel muy destacado en los rituales funerarios. Este proceso de transformación fue lento y desigual, y no se generalizó hasta comienzos o hasta el segundo cuarto del s. IV a. C. (Quesada, 1997a: 611; Quesada, 2002: 42).

\section{LA NECRÓPOLIS DE EL CASTILLO Y SU CONTEXTO}

La necrópolis de El Castillo se sitúa en el valle medio del Ebro, al norte del municipio de Castejón, en la comarca geográfica de la Ribera de Navarra. Limita al Norte con Valtierra, con Tudela al Este, al Sur y al Suroeste con Corella y con Alfaro (La Rioja) por el Oeste (Fig. 1).

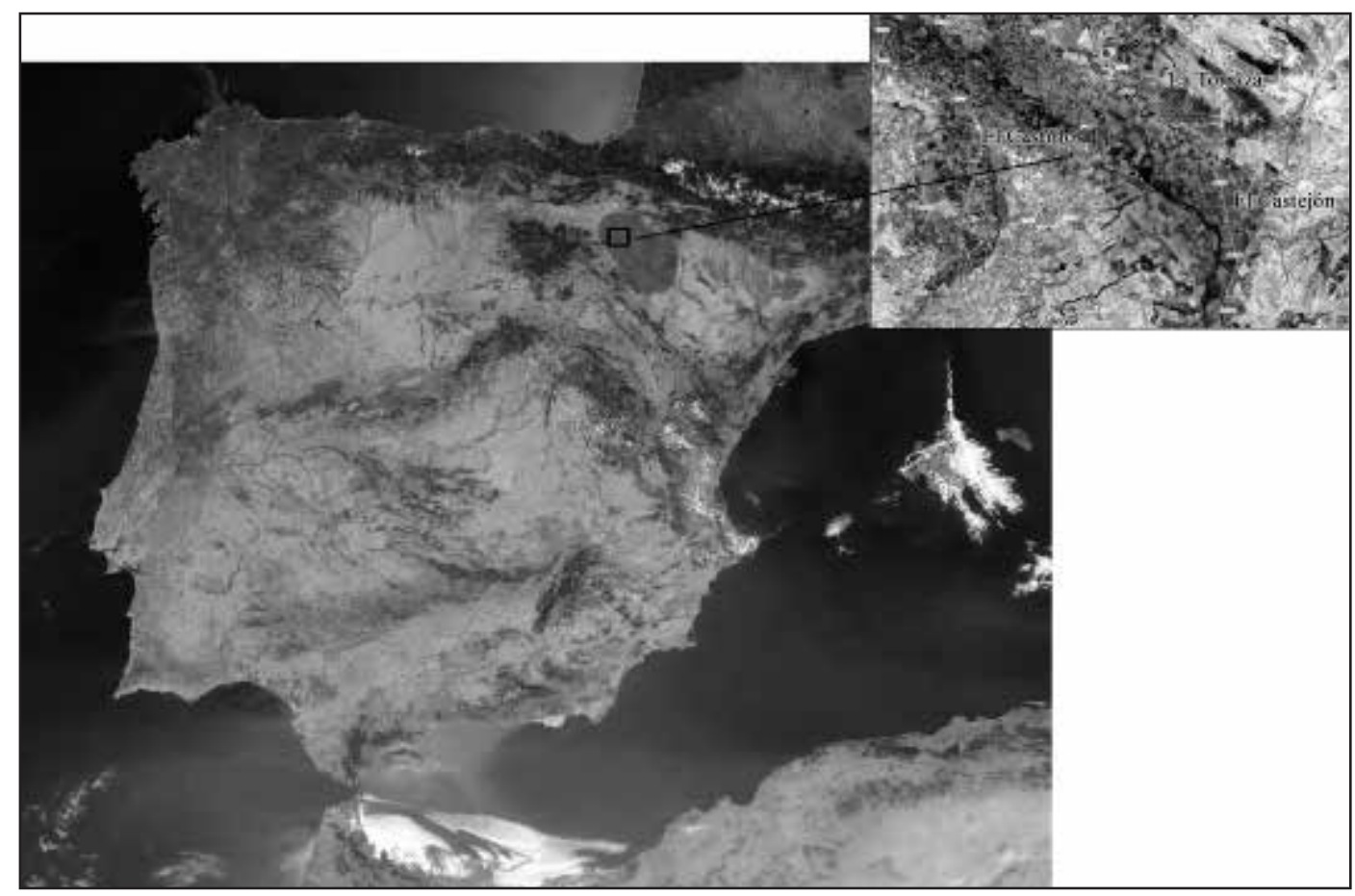

Figura 1. Valle medio del Ebro. Necrópolis de incineración protohistóricas situadas en su extremo occidental. 
El yacimiento se ubica en la extensa planicie que forman las terrazas del río Ebro. Sus coordenadas UTM son x: 609.166 // y: 4.669.858. El paisaje, en la actualidad, se encuentra fuertemente humanizado. En las últimas décadas estos parajes han sido sometidos a una profunda transformación, primero al adecuar los terrenos a las nuevas necesidades agrícolas $\mathrm{y}$, posteriormente, por la construcción de dos centrales térmicas de ciclo combinado y de un polígono industrial (Fig. 2). El aspecto que presentaba la necrópolis en la fecha de su descubrimiento era el de una suave loma, un pequeño montículo artificial como resultado de la acumulación de construcciones tumulares (Fig. 3). La distancia que le separa de la plataforma superior del cerro donde se ubicó el poblado es de 450 m, en dirección sureste.

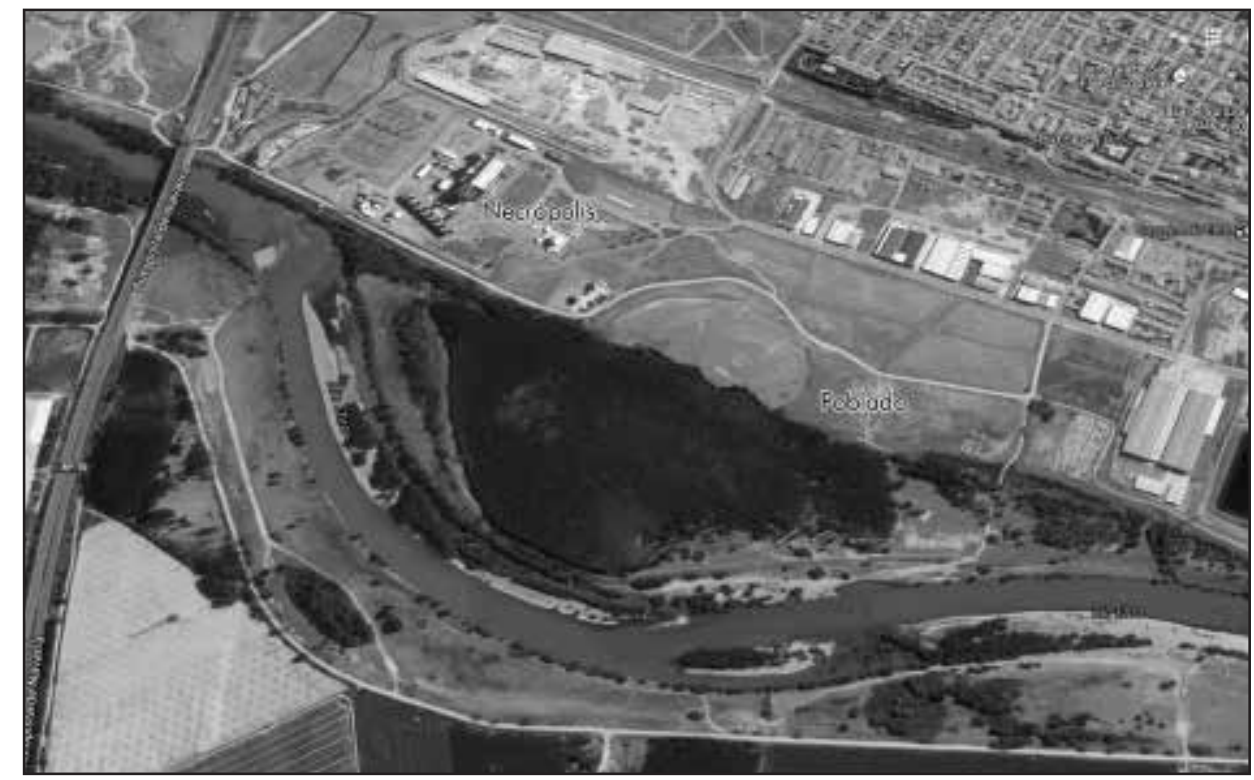

Figura 2. Poblado y necrópolis de El Castillo (Castejón, Navarra).

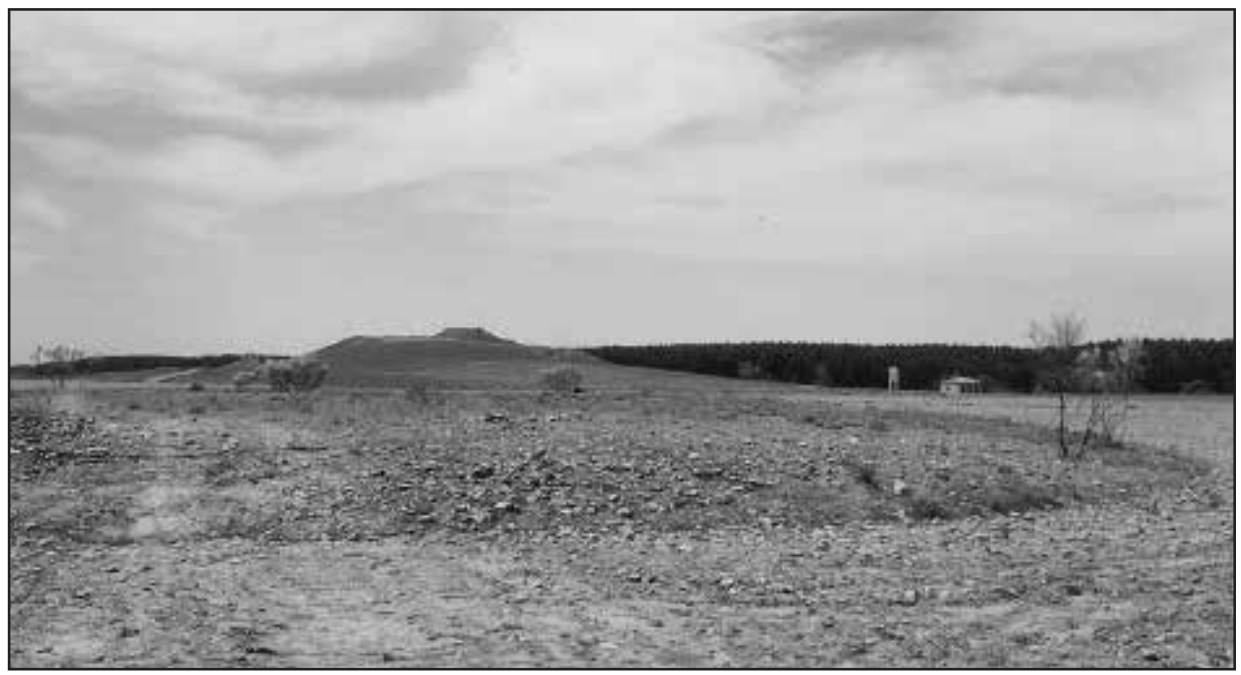

Figura 3. Año 1999. Aspecto de la necrópolis, en primer término, antes de comenzar la excavación. (Foto Gabinete Trama S. L.) 
El Ebro, que discurre a escasos metros de distancia, focaliza los recursos hídricos. En este tramo, el agua fluye a menor velocidad debido a una prolongada sucesión de meandros, que da lugar a un paisaje en el que se combinan meandros activos con otros estrangulados y abandonados (Floristán, 1995: 491) (Fig. 4). El trazado en este sector del río, por su disposición quebrada, reúne unas condiciones especialmente favorables para atravesar su cauce. La posición estratégica del poblado y la necrópolis, dominando el vado del río, y la capacidad para ejercer un control sobre los intercambios comerciales que se realizaban siguiendo el curso del Ebro, son elementos claves para entender el grado de desarrollo social y económico alcanzado por esta comunidad.

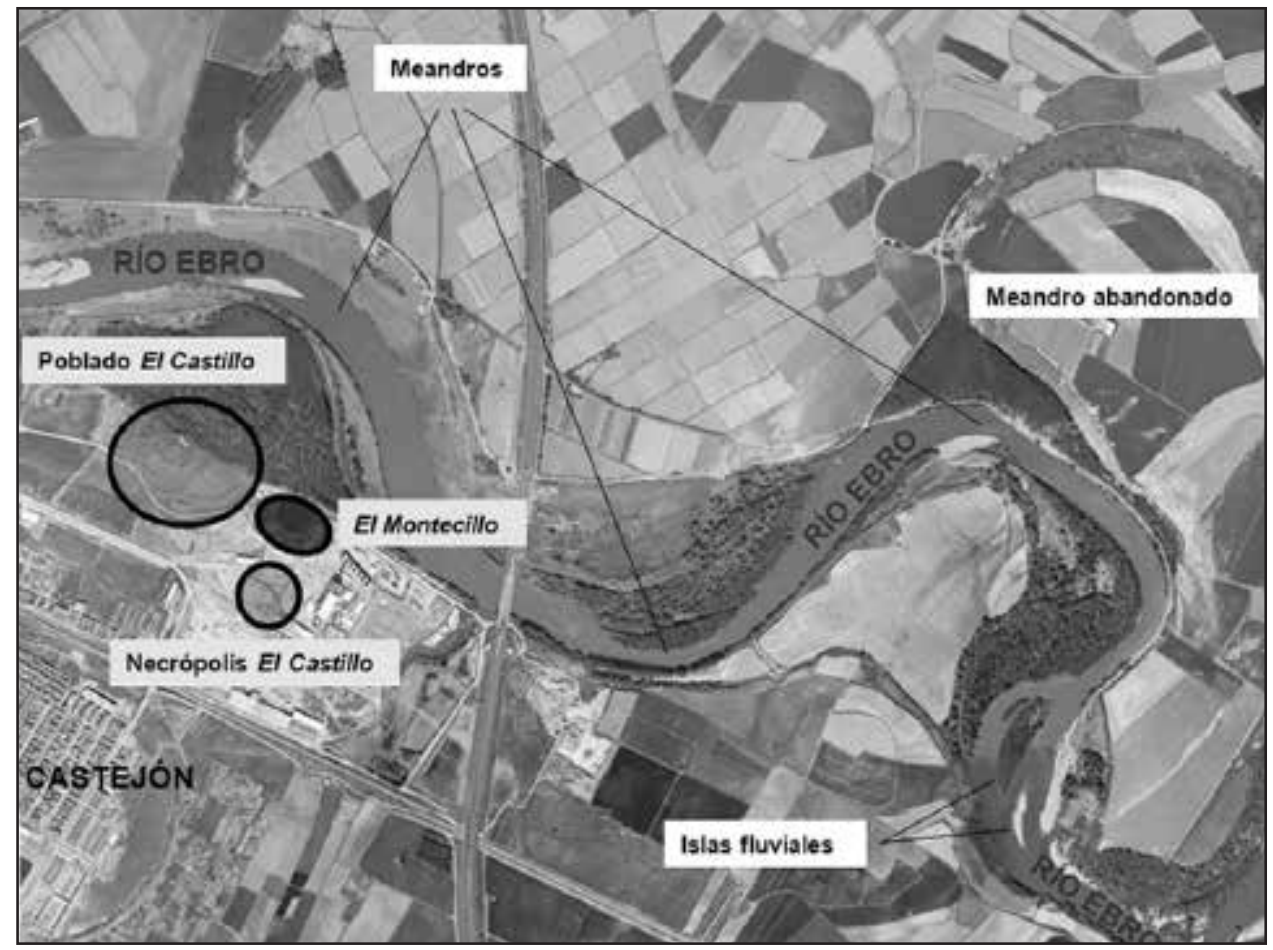

Figura 4. Ortofotomapa. Trazado del río Ebro a su paso por la localidad de Castejón.

El valle medio del Ebro es un espacio considerado de frontera desde la Prehistoria (Pelegrín, 2003: 14; Oliver, 2012: 418), con un evidente valor geoestratégico que se ha mantenido a lo largo del tiempo. Es un territorio bien comunicado y de fácil acceso, al que su posición le otorga un inherente potencial como zona de enlace o mediación entre el Mediterráneo y el interior peninsular, y también entre éste y los grupos humanos situados a ambos lados de los Pirineos. El río Ebro ha sido el eje vertebrador de este territorio, generando a su alrededor áreas de gran riqueza agrícola y ganadera, y actuando como vía de comunicación y de comercio desde la Antigüedad. Estas condiciones ejercieron una influencia decisiva en la formación de sociedades estratificadas y complejas desde fechas tempranas.

Las cuestiones referentes al entorno geográfico, al desarrollo de las intervenciones arqueológicas y a las características de la necrópolis ya han sido extensamente tratadas en anteriores artículos a los que nos remitimos (Faro et alii, 2002-2003; Faro y Unzu, 2006; Faro, 2015: 31-35; Faro, 2017). 
Los enterramientos ocuparon una superficie elevada que, atendiendo a los datos derivados de la intervención arqueológica, pudo superar las 2 ha. No obstante, el área no roturada, donde las estructuras funerarias (e. f.) mantenían su disposición original, se limitaba a una parcela de, aproximadamente, $3.000 \mathrm{~m}^{2}$. Las sucesivas campañas efectuadas entre los años 2000 y 2006 han supuesto la excavación de una tercera parte de la superficie intacta del yacimiento. En las citadas campañas, se han identificado y delimitado 194 estructuras funerarias, completando el proceso de excavación y registro en 178. De ellas 119 se encontraban ubicadas en el área no roturada del cementerio (Faro, 2002; Faro et alii, 2002-2003; Faro y Unzu, 2006).

El Castillo responde al modelo de necrópolis extensa como resultado de una explotación prolongada en el tiempo, que se prolongó al menos entre los s. VI y III a. C., y con una ocupación progresiva y ordenada del espacio, de sur a norte. Las sepulturas pertenecientes a la etapa inicial de uso del cementerio se ubicaron en el extremo sur y, de forma paulatina, fueron recortando la distancia que existía con el poblado. En este sentido, presenta una organización similar a la documentada en la necrópolis vaccea de Las Ruedas (Padilla de Duero, Valladolid) (Romero et alii, 2009: 239).

Las necrópolis de incineración más cercanas a El Castillo, las situadas en el extremo occidental del valle medio del Ebro, mantienen una serie de rasgos comunes. Las conexiones en aspectos tan diversos como la ubicación de los cementerios, su relación con los poblados, la organización interna de las tumbas, la arquitectura funeraria o los rituales y su evolución a lo largo del tiempo, son evidentes en El Castejón (Arguedas, Navarra) (Castiella y Bienes, 2002), en La Torraza (Valtierra, Navarra) (Maluquer, 1953; Castiella, 2007) y, en menor medida, en La Atalaya (Cortes, Navarra) (Maluquer y Vázquez de Parga, 1956; Castiella, 2005). Un escenario lógico si tenemos en cuenta que se trata de necrópolis coetáneas, con un período de utilización dilatado en el tiempo, en una posición de proximidad geográfica y que, como ya se ha indicado, en este tramo el Ebro no suponía una frontera natural infranqueable al poder vadearse con relativa facilidad.

Las estructuras funerarias de El Castillo constituyen conjuntos cerrados, con materiales que pueden seriarse y fecharse con una cronología relativa que, a su vez, se puede contrastar con la que proporciona la estratigrafía. Las superposiciones, reutilizaciones e intrusiones observadas en el desarrollo de la excavación, a través de la estratigrafía, han permitido establecer una secuencia de los conjuntos. Se han identificado tres fases cronológicas para las 119 sepulturas halladas en el área intacta de la necrópolis (Fig. 5) (Faro, 2015: 35-42).

En la necrópolis de El Castillo se catalogaron 70 piezas, que formaron parte de 7 espadas, 5 soliferrea, 22 lanzas y/o jabalinas, 12 escudos y 3 cascos. ${ }^{1}$ La media de armas por tumba se situaría en 0,41 , no obstante esta cifra debe ser analizada con detenimiento, ya que no obedecen a un comportamiento uniforme a lo largo del tiempo. En la Fase I no se documentan armas y en la Fase II la media es muy baja, de 0,13. En cambio, en la Fase III se produce un ascenso muy significativo, hasta alcanzar 1,09. Pese a ello, el reparto de las armas en las tumbas no es homogéneo, se concentran formando panoplias complejas en un número reducido de sepul-

\footnotetext{
1 Este artículo representa una parte de mi tesis doctoral (Faro, 2016), un extenso trabajo de investigación sobre la necrópolis de El Castillo y los ritos funerarios en el valle medio del Ebro del que, por el momento, se han publicado algunos estudios parciales (Faro, 2015 y 2017). Fue dirigido por la Dra. Mar Zarzalejos, codirigido por la decana Ma Jesús Peréx y defendido en la UNED de Madrid en febrero de 2016. El tribunal estuvo formado por la Prof. Teresa Chapa, el Prof. Alberto Lorrio y el Prof. Gabriel Sopeña. El segundo de los tres volúmenes de la tesis, el más extenso, está dedicado en exclusiva al análisis de los ajuares recuperados en esta necrópolis y es el resultado de una amplia investigación, imprescindible para dar respuesta al elevado número de piezas depositadas en el interior de los túmulos y a su heterogeneidad. Por este mismo motivo, se tuvo que descartar la opción de abordar en un artículo de estas características el estudio conjunto de todo el armamento (Faro, 2016: 685-751) y se optó por centrarlo en el análisis de las espadas, al tratarse de piezas singulares y de elementos representativos y muy valorados por estas sociedades de marcado carácter guerrero.
} 


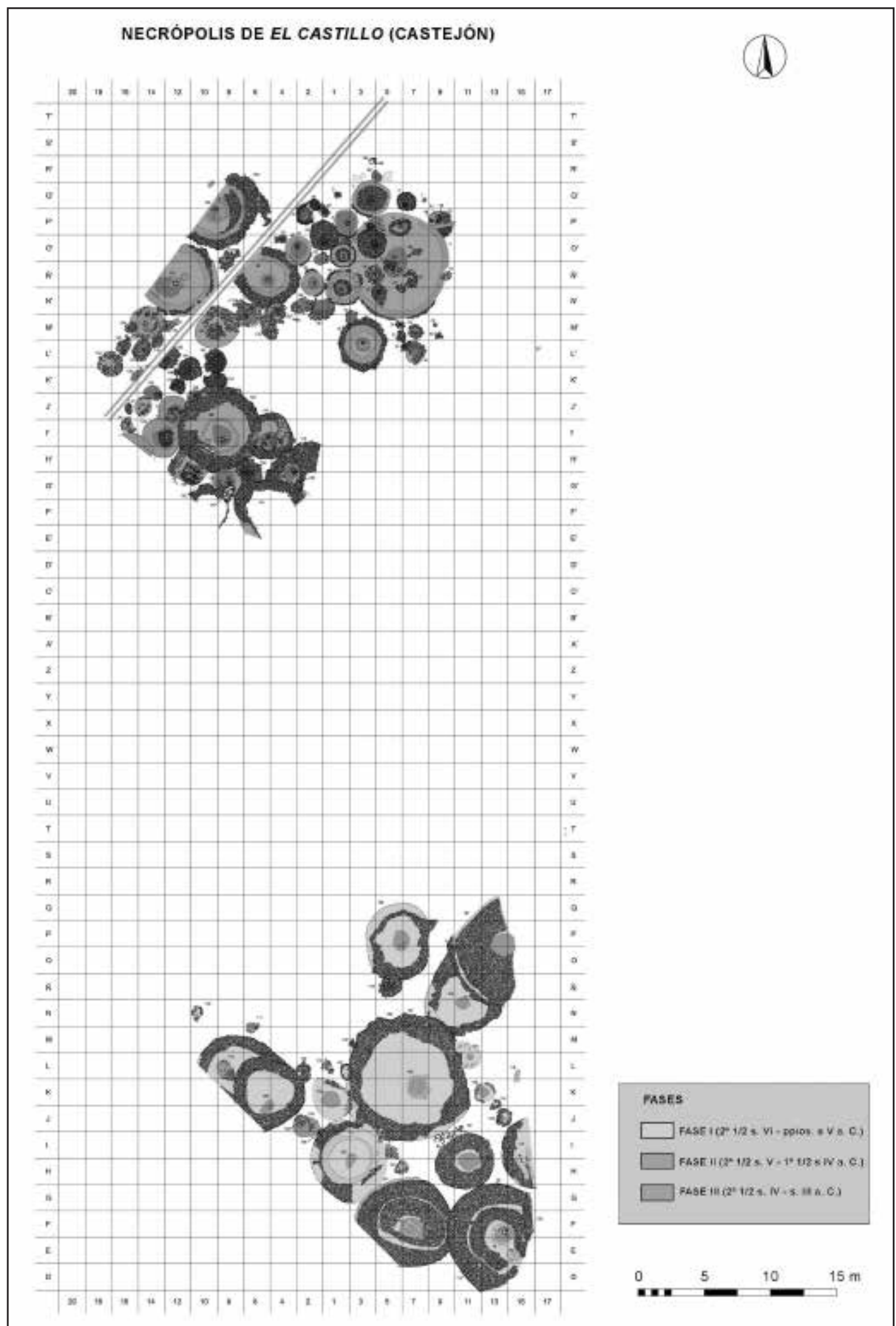

Figura 5. Planimetría con la situación de las estructuras funerarias (Faro, Cañada y Unzu, 20022003, 53, modificada). 
turas. De las sesenta y una tumbas excavadas en la Fase III, en cuarenta y seis no se hallaron este tipo de objetos, lo que indica que eran acumulados principalmente por un sector concreto de la población, la élite de guerreros.

\section{ARMAMENTO OFENSIVO. LAS ESPADAS}

\subsection{CARACTERIZACIÓN TÉCNICA Y TIPOLÓGICA}

La espada en sociedades de marcado carácter guerrero, como la celtibérica o la ibérica, era el arma ofensiva por excelencia y un símbolo de prestigio y de primacía social (AlmagroGorbea, 1997: 216). La producción de objetos de estas características requería del dominio de una técnica de fabricación compleja y de una continua búsqueda de materiales cada vez más resistentes, flexibles y duraderos.

En la necrópolis de El Castillo se han identificado 7 ejemplares, 6 más o menos completos y 1 fragmento de vaina, que fueron depositados en el interior de seis sepulturas del área intacta de la necrópolis (e. f. 11, 23, 44, 137, 141 y 167). El metal utilizado en la elaboración de estas piezas fue el hierro. En ocasiones y con fines estéticos, podía combinarse con otros metales, como se observa en la decoración damasquinada de hilos de bronce que luce la vaina del ejemplar 23.6.

Todas las espadas documentadas, a excepción de la pieza 137.9, mantienen la mayoría de los elementos que las integraban, aunque presentan un alto grado de deterioro, como resultado de los daños derivados del ritual de cremación (incremento de la oxidación, grietas, fragmentaciones, fusión con otros elementos metálicos, etc.). Las labores de registro y clasificación están, en parte, condicionadas por esta circunstancia, a la que se suma el pliegue intencionado de cuatro ejemplares $(23.6,44.10,141.10$ y 167.7$)$ de forma previa a su amortización definitiva en las tumbas.

La trascendencia social y simbólica de las espadas también tiene su reflejo en la riqueza decorativa aplicada a este tipo de armas. Los motivos se concentran principalmente en las empuñaduras y en las vainas, elementos especialmente sensibles a las altas temperaturas que se alcanzaban en las piras funerarias. En el caso de las empuñaduras, porque solían estar realizadas en materiales perecederos. En las vainas, por su parte, también recurrían al empleo de materiales orgánicos o al uso de placas metálicas muy finas, que el fuego puede fragmentar, fundir y deformar con relativa facilidad.

Otro aspecto significativo del conjunto recuperado en El Castillo es el hecho de haberse registrado tres modelos muy diferentes de espadas: tres ejemplares de antenas, tres de La Tène y una falcata (Fig. 6). Esta diversidad, en objetos con un círculo de difusión tan restringido como el de las espadas, debemos considerarla como un testimonio de la importancia de este emplazamiento y de la singularidad que le confiere su situación estratégica, que facilita los contactos con el ámbito meseteño, mediterráneo y ultrapirenaico.

Las referencias a espadas en el valle medio del Ebro son escasas. La más antigua corresponde a los ejemplares recuperados en el depósito de armas de Etxauri (Bosch Gimpera, 1921: láms. I-V; Castiella y Sesma, 1988-1989). En contextos funerarios tan sólo se identificaron en la necrópolis de Busal (Uncastillo, Zaragoza), de la que proceden varios fragmentos de una espada de La Tène (Burillo, 1977: 52 y 57; Royo, 1980: 275; García Jiménez, 2011: 240, fig. 257), y en La Atalaya (Cortes, Navarra), de la que procede una espada de antenas asociada a la sepultura AA10 y otros tres fragmentos de difícil adscripción tipológica (Maluquer y Vázquez de Parga, 1956: 424, fig. 14; Ruiz Zapatero, 1985: 894-895; Castiella y Sesma, 1988-1989: 


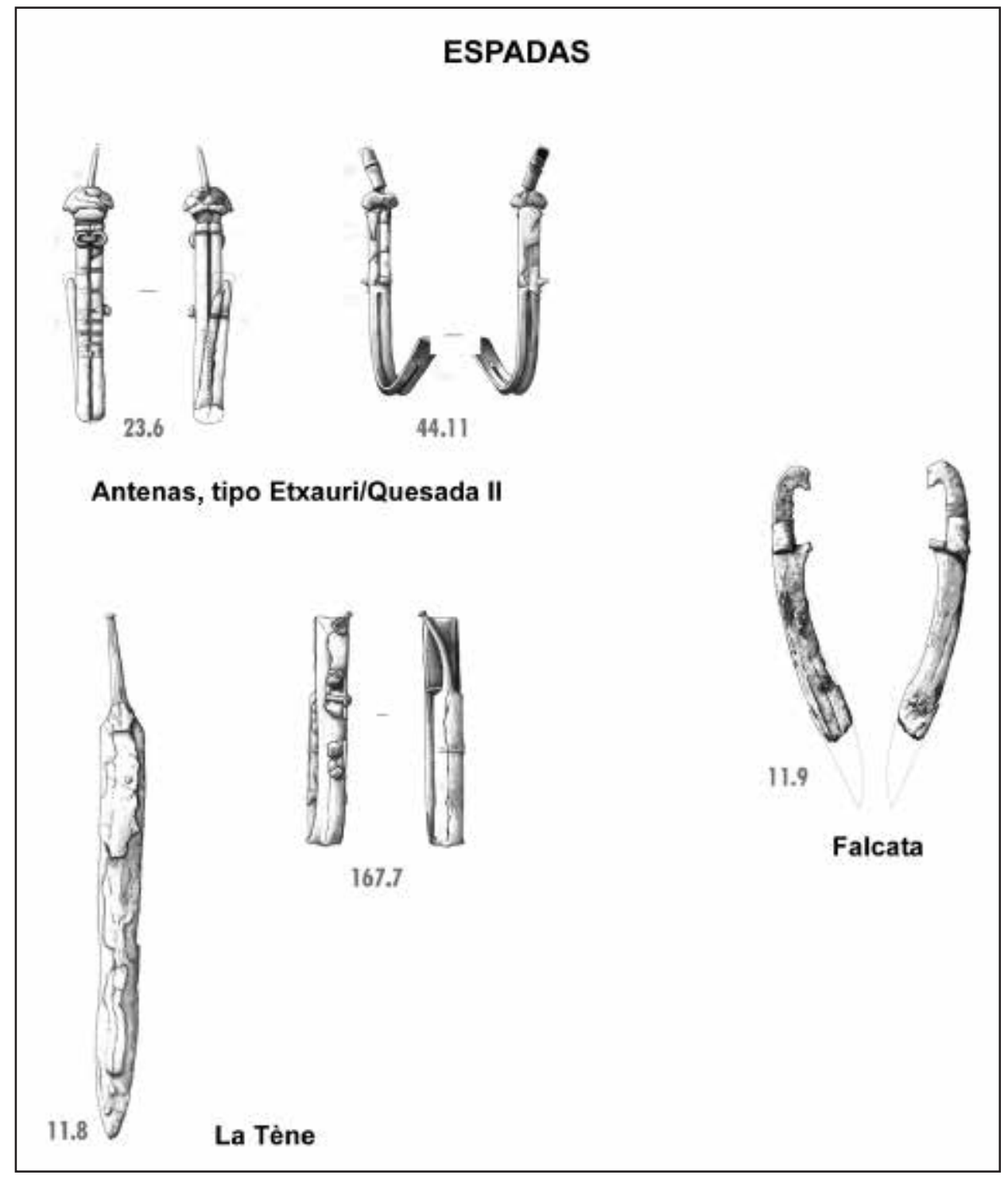

Figura 6. Tipología de las espadas identificadas en la necrópolis de El Castillo.

385, fig. 2; Castiella, 2005: 194-195, fig. 109). El conjunto más numeroso fue el recuperado en el depósito de La Azucarera (Alfaro, La Rioja) (Iriarte et alii, 1996; Quesada, 1997a: 255; García Jiménez, 2011: 148), cuya amortización tuvo lugar ya en época romana. Asimismo, también se han registrado tres ejemplares de espadas de La Tène en el poblado de La Oruña (Vera del Moncayo, Zaragoza) (Bona et alii, 1983: láms. IX, X y XI; Quesada, 1997a: 255; García Jiménez, 2011: fig. 284, 302 y 309) y, en fechas recientes, una falcata en el poblado de Peñahitero (Fitero, Navarra) (Olcoz, 2011).

La clasificación tipológica de las espadas se ha ajustado, en gran medida, a los planteamientos expuestos por Quesada para el armamento ibérico (Quesada, 1997a) y a las aportaciones de García Jiménez sobre las espadas de tipo Etxauri/Quesada II (García Jiménez, 2006) y sobre el armamento de influencia de La Tène en la península ibérica (García Jiménez, 2011). También se han tenido en cuenta las propuestas desarrolladas por otros autores para determi- 
nados modelos, como es el caso de Cabré de Morán (1956 y 1990), Cuadrado (1989), Lorrio (1997), Rapin (1989 y 1999) o Lejars (2003).

\section{Espadas de antenas tipo Etxauri/Quesada II}

El tipo Etxauri/Quesada II forma parte de las espadas de antenas. Responde, por tanto, al esquema de fabricación característico de estas armas. Presenta una hoja, generalmente corta, de doble filo, estrecha y apuntada. Los ejes suelen ser rectos y, en algunos casos, con nervio central que se prolonga en una espiga que, a su vez, constituye el esqueleto de la empuñadura. Ésta, por su parte, queda estructurada por dos cilindros troncocónicos huecos que envuelven las cachas de materia orgánica que sujetan la espiga. La guarda es curva, sin llegar a ser envolvente, y el pomo adquiere la forma de unas antenas bastante desarrolladas que terminan en sendos remates con disco central. Las vainas son enterizas de hierro, con embocadura curva, ranura longitudinal en el centro y contera con extremo recto (Quesada, 1997a: 207, fig. 116; García Jiménez, 2006: 22, fig. 3) (Fig. 7).



Figura 7. Partes y elementos que integran una espada de tipo Etxauri/ Quesada II (según García Jiménez, 2006: fig. 3).

La denominación tipo Etxauri fue acuñada por $\mathrm{M}^{\mathrm{a}} \mathrm{E}$. Cabré de Morán a partir de un ejemplar procedente de esta localidad (Cabré de Morán, 1956: 755), que actualmente se encuentra depositado en el Museo de Navarra. Esta investigadora defendió la antigüedad de la espada, su origen aquitano y la posible vía de penetración a través del pirineo navarro, una postura que, en gran medida, también comparten todos los autores que han estudiado este tipo de armas. F. 
Quesada, en su obra sobre el armamento ibérico, estableció una clasificación tipológica para las espadas de antenas atrofiadas peninsulares de la Segunda Edad del Hierro, incluyendo este modelo en su tipo II (Quesada, 1997a: 207). Por último, en un trabajo más reciente, G. García Jiménez realizó un exhaustivo análisis tecnológico y morfológico de las espadas tipo Etxauri/ Quesada II que le permitió, en función de las variaciones e innovaciones detectadas, diferenciar cuatro grupos (García Jiménez, 2006: 23).

La cronología de este modelo de espada, en función del aspecto arcaico de las antenas y de la guarda, abarca, según Schüle, desde mediados del s. VI hasta mediados del s. V a. C. (Schüle, 1969: 96). Cabré de Morán retrasó notablemente el origen de estas producciones, situándolas principalmente en el s. IV a. C., con ejemplares arcaizantes que alcanzarían el s. V a. C. (Cabré de Morán, 1990: 209). Lorrio, siguiendo este mismo patrón, clasifica las espadas tipo Etxauri en sus fases IIA1 y IIA2 del alto Tajo-alto Jalón y IIA del alto Duero, entorno a los s. V-IV a. C. (Lorrio, 1997: 156-183). Quesada, por su parte, también propone fechas comprendidas entre el s. V y un momento avanzado del s. IV a. C. (Quesada, 1997a: 207). Este mismo planteamiento es el que sugiere García Jiménez cuando describe las cuatro fases diferenciadas de la secuencia evolutiva de estas armas (García Jiménez, 2006: 56-57).

La mayoría de los veinticuatro ejemplares documentados, pese al nombre atribuido, se concentran en la Meseta oriental, fundamentalmente en las necrópolis de Soria y Guadalajara. En territorio navarro, hasta la fecha tan sólo se habían hallado entre las piezas del lote de Etxauri. En El Castillo, se han catalogado dos espadas (23.6 y 44.11) y un fragmento de la vaina de una tercera (137.9) de tipo Etxauri/Quesada II, en todos los casos se recuperaron en el interior de sepulturas correspondientes a la Fase III ( $2^{\mathrm{a}} 1 / 2 \mathrm{~s}$. IV - s. III a. C.).

Ejemplar 23.6

Esta espada procede del interior de un rebaje o loculus excavado en el terreno natural y situado debajo del lugar elegido para colocar la urna (Fig. 8). Junto a ella también depositaron un caldero de bronce, además de otras armas y utensilios metálicos relacionados con ritos de sacrificio y banquete (Fig. 9). Ubicaciones similares se han documentado para los ejemplares recuperados en las e. f. 44, 141 y 167.

En el estado actual de la pieza ha influido de forma decisiva la cremación. La espada fue doblada de forma previa a su amortización en la tumba y de la empuñadura no conserva las antenas, ni los cilindros que envolvían las cachas de materia orgánica que sujetaban la espiga. También se desprendió el extremo de la contera (Fig. 10).

La longitud máxima conservada es de $57,8 \mathrm{~cm}$. La espiga tiene $6 \mathrm{~cm}$ de largo y es de $\mathrm{sec}-$ ción cuadrada, de $0,8 \mathrm{~cm}$ de lado. La guarda es curva, sin que puedan apreciarse las terminaciones de los gavilanes. Tiene una amplitud de $6,6 \mathrm{~cm}$ y un desarrollo de $2 \mathrm{~cm}$. La hoja es recta, de doble filo y con nervio central marcado. Su longitud de $49,8 \mathrm{~cm}$ y su anchura en la parte central de $2,8 \mathrm{~cm}$. Entre la guarda y la vaina se observa la existencia de una pieza rectangular de hierro de 1,6 cm de anchura, que no corresponde a la estructura inicial de la espada (Fig. 11). Fue añadida con posterioridad para ajustar la hoja al tamaño de la vaina, que es sensiblemente más corta. La presencia de este elemento indica una reparación de la espada, con el fin de reutilizar una vaina ricamente decorada. Una práctica que constituye un buen ejemplo del valor atribuido a las armas, como objetos con un marcado carácter simbólico que podían ser donados, heredados, obtenidos como botín de guerra, etc. En este caso, la reparación pudo responder a un intento de adaptar la pieza a las necesidades de su nuevo propietario. 


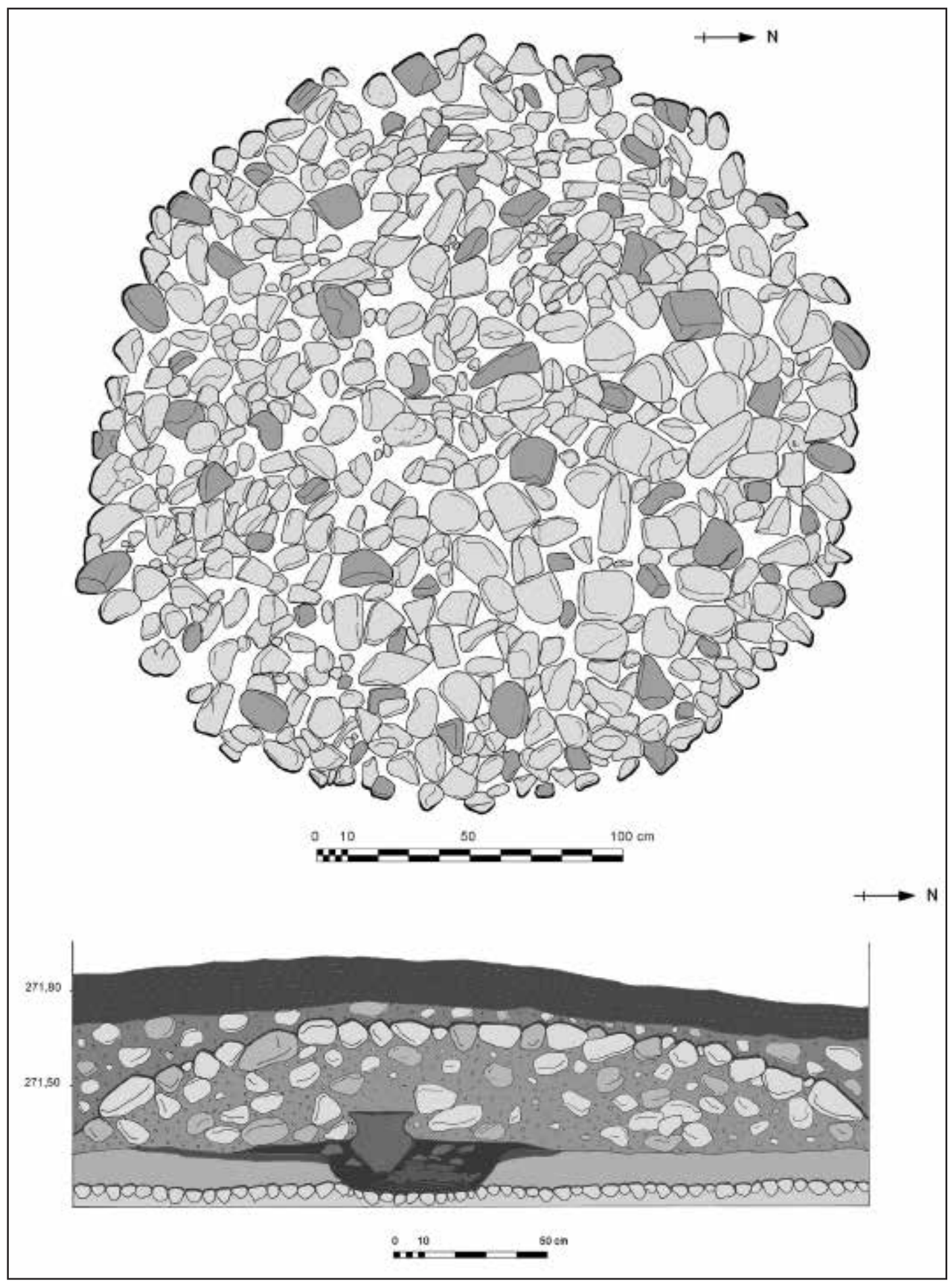

Figura 8. E.F. 23. Planta y sección del túmulo. 


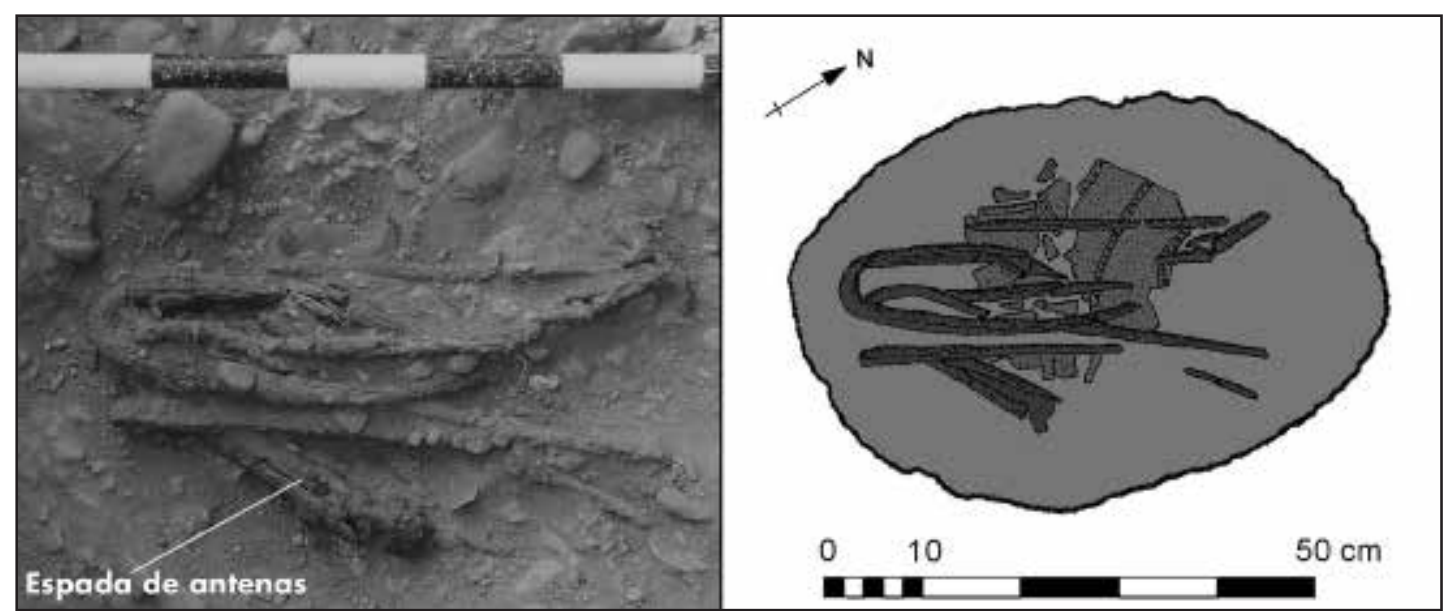

Figura 9. E.F. 23. Depósito de armas en el interior de un pequeño loculus. Entre las piezas amortizadas se recuperó un soliferreum y una espada de antenas de tipo Etxauri/Quesada II. (Foto Gabinete Trama S. L.)

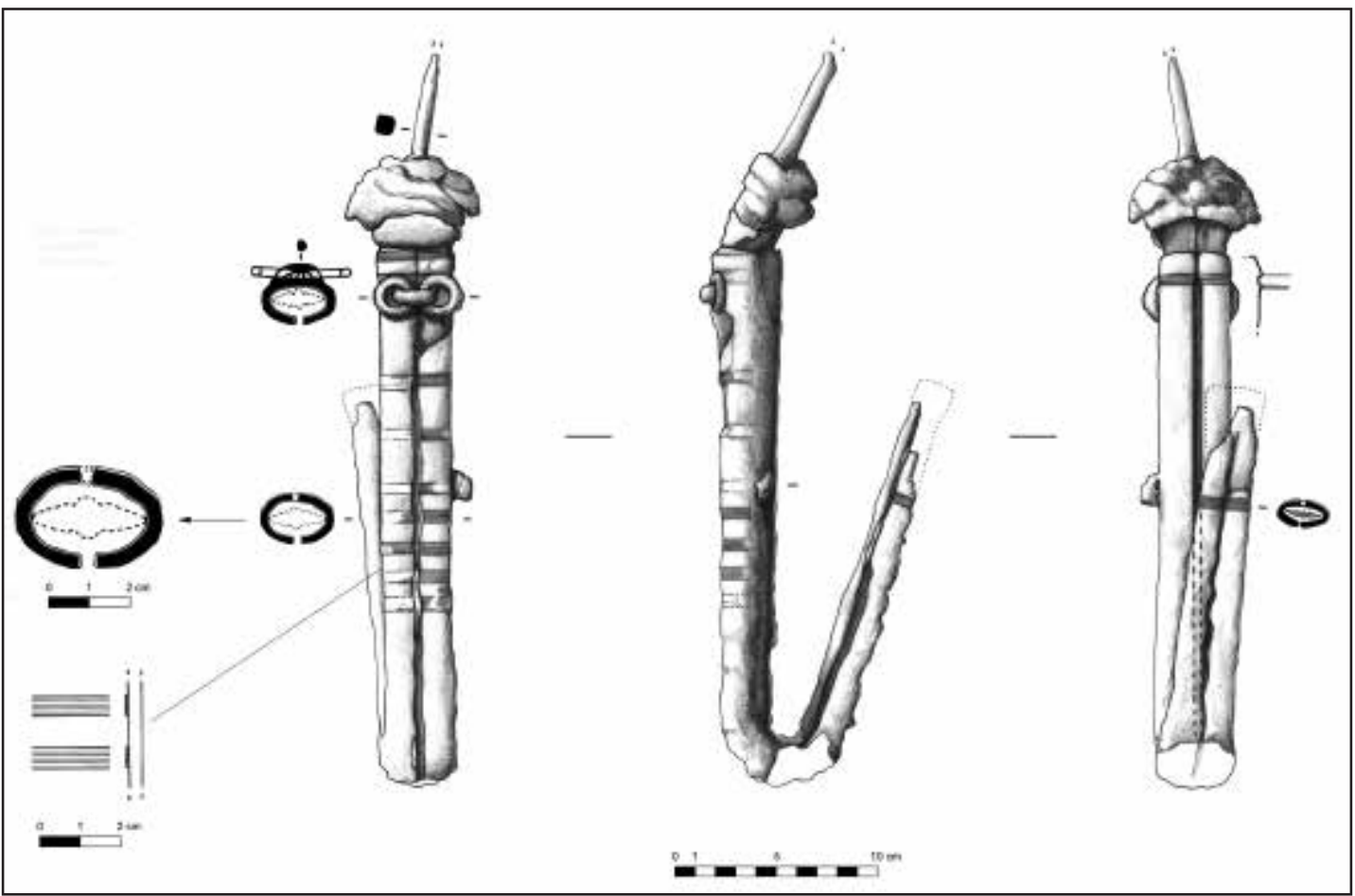

Figura 10. 23.6. Espada de antenas tipo Etxauri/Quesada II.

La vaina es enteriza y se encuentra fundida a la hoja. Tiene $47,2 \mathrm{~cm}$ de longitud y su anchura es de 3,6 cm. En su elaboración emplearon dos piezas unidas mediante soldadura que dejan en el centro, tanto en el reverso como en el anverso, una larga ranura longitudinal. La contera se abre de forma muy ligera y termina en horizontal. Para la suspensión de la espada cuenta en el anverso, cerca de la embocadura, con una hembrilla horizontal que articula dos anillas circu- 


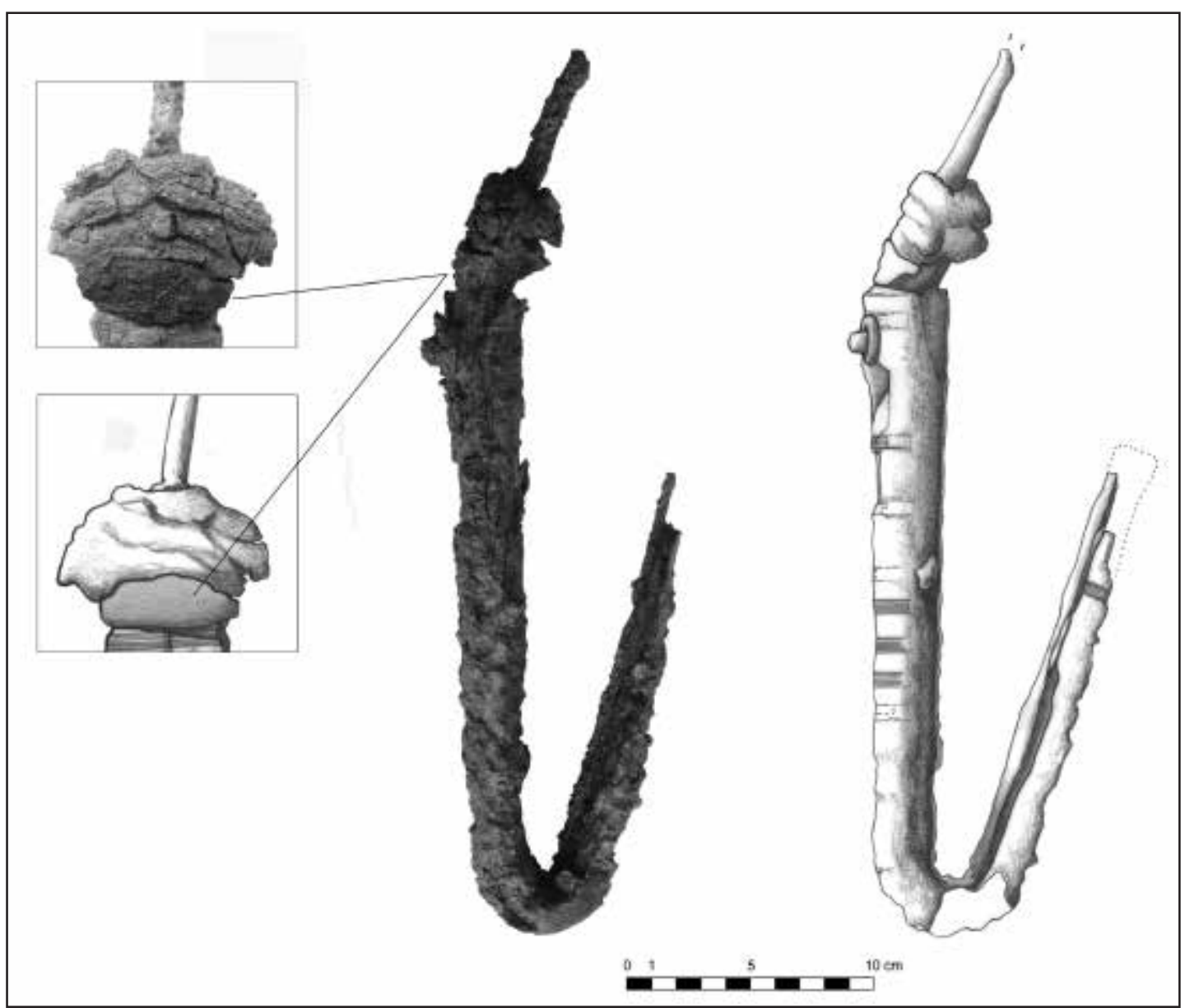

Figura 11. 23.6. Espada de antenas tipo Etxauri/Quesada II. Pieza añadida para ajustar la vaina al tamaño de la hoja. (Foto Gabinete Trama S. L.)

lares y en lado izquierdo con un anclaje lateral. Un sistema similar al que se documenta en una espada procedente de la necrópolis de El Altillo (Aguilar de Anguita, Guadalajara) (Schüle, 1969: Taf. 6.2). Hembrillas horizontales, aunque con diferentes características, también se registran en un ejemplar de la colección Guttman (Barril, 2004: 23) y en otro procedente del municipio de Etxauri (Navarra) (Bosch Gimpera, 1921: lám. I.1). Estos elementos contribuían a reforzar la solidez de este tipo de vainas, que acusaban una cierta fragilidad debido a la amplitud de la ranura y a la naturaleza de sus puntos de sujeción, que se limitaban a la soldadura entre las placas y al extremo de la contera (García Jiménez, 2006: 50).

La espada presenta decoración geométrica realizada con hilos de bronce, mediante técnica de damasquinado. Es probable que se adornara gran parte de la empuñadura y el anverso de la vaina. El deficiente estado de conservación de la guarda, laminada y con numerosas grietas horizontales y transversales, únicamente ha permitido identificar restos de óxido de bronce. En la vaina, en cambio, sí se aprecia con claridad una decoración de bandas horizontales (Fig. 12). Todavía se observan ocho de esas franjas, una de ellas situada en el extremo distal. En territorio peninsular, estos motivos lineales se concentran en las espadas del tipo Etxauri/Quesada II. Se han registrado en la espada del Museu de Llagostera (Girona) (García Jiménez, 2006: fig. 4), en un ejemplar con vaina del depósito de Etxauri (Navarra) (Bosch Gimpera, 1921: lám. 
I.1), en otro de la colección Guttman (Barril, 2004: 23) y en un cuarto procedente de El Altillo (Aguilar de Anguita, Guadalajara) (Schüle, 1969: Taf. 6.2).

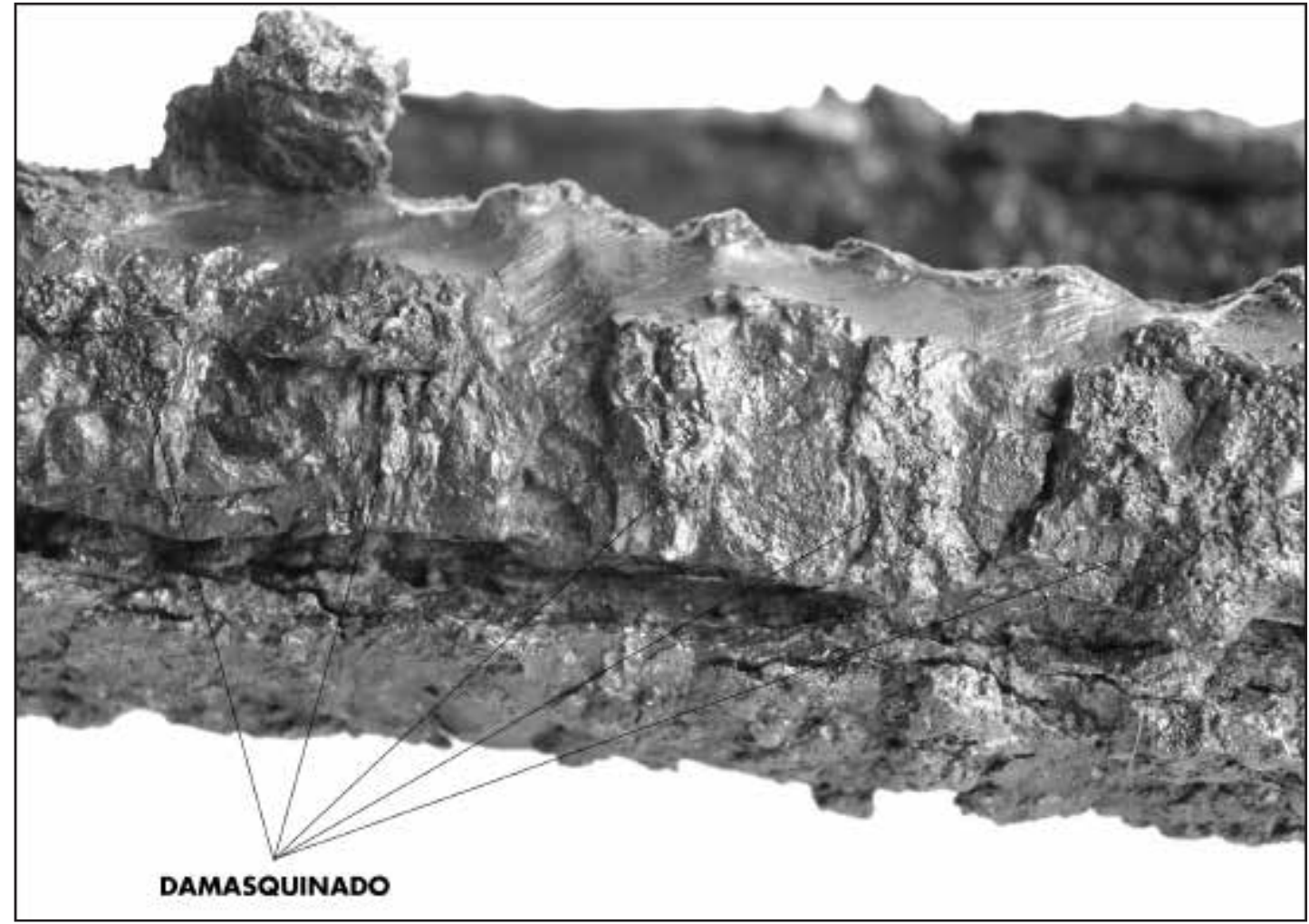

Figura 12. 23.6. Espada de antenas tipo Etxauri/Quesada II. Restos de decoración mediante técnica de damasquinado, con hilos horizontales de bronce que decoraban la vaina. (Foto Gabinete Trama S. L.)

La ornamentación de las espadas de antenas y las vainas del tipo Etxauri/Quesada II, con el uso del damasquinado y la presencia de círculos y/o de bandas paralelas, es uno de los aspectos en los que se advierte con mayor nitidez la influencia aquitana (Mohen, 1980: 63-65, fig. 123; García Jiménez, 2006: 50). Un buen ejemplo lo constituyen las espadas de antenas y las vainas halladas en la necrópolis de Avezac-Prat (Bagnères-de-Bigorre, Midi) (Pilloy, 1899: pl. III y V) (Fig. 13).

El ejemplar 23.6 debe incluirse entre las espadas de tipo Quesada II, a las que se atribuye una cronología situada entre los s. V - IV a. C. (Quesada, 1997a: 207). Atendiendo a sus características técnicas y tipológicas, se sitúa dentro del denominado Grupo II de la clasificación propuesta por García Jiménez (2006: 39-42, fig. 10 y 11). Combina algunos rasgos arcaizantes, como la decoración damasquinada de bandas longitudinales de la vaina, el empleo de una hembrilla de suspensión horizontal o la longitud de la hoja (sin llegar a las dimensiones de piezas como la del Museo de Llagostera); con otros elementos evolucionados que caracterizan a la etapa de máxima difusión de este modelo, como la empuñadura de espiga, la vaina enteriza de hierro, la ranura o el anclaje lateral. En la península ibérica únicamente se han registrado tres espadas con un diseño similar, los mencionados ejemplares procedentes de Etxauri (Navarra), de la colección Guttman y de la necrópolis de El Altillo (Aguilar de Anguita, Guadala- 


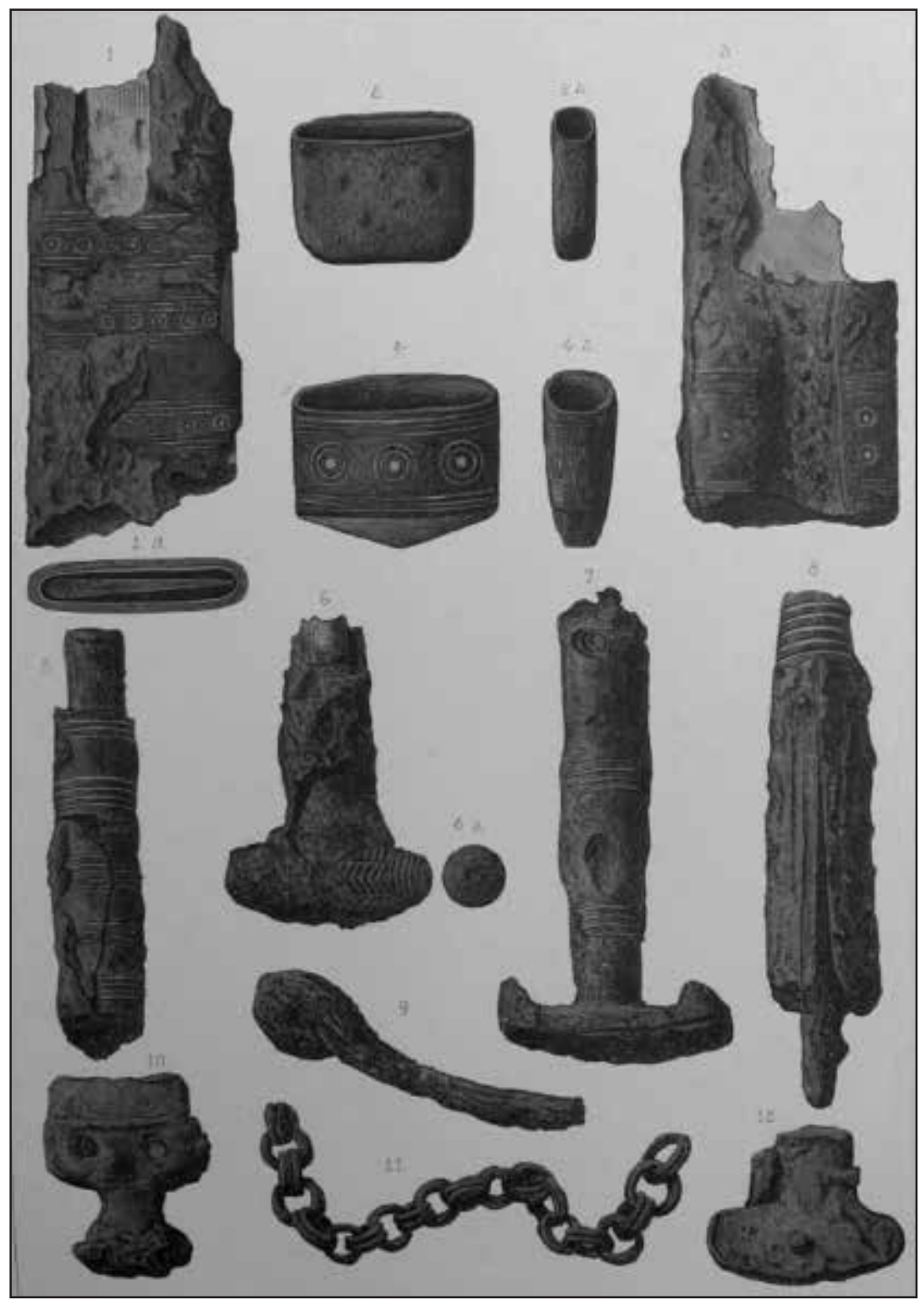

Figura 13. Necrópolis de Avezac-Prat (Bagnères-de-Bigorre, Midi). Fragmentos de espadas, vainas y otras armas con damasquinados de hilos de bronce (Pilloy, 1899: Pl. V).

jara). La cronología propuesta por García Jiménez para estas espadas se sitúa entre el segundo cuarto y mediados del s. V a. C. Aunque, como reconoce el propio autor, es un planteamiento completamente hipotético al no contar con ningún contexto arqueológico fiable. Para la pieza de El Altillo, incluso apunta una cronología más reciente (García Jiménez, 2006: 54-55).

La espada 23.6 de El Castillo formaba parte de una panoplia compleja, que contaba con un escudo de tipo caetra, del que se han recuperado las dos anillas móviles para el sistema de suspensión del correaje del tipo B de Arcobriga (Lorrio y Sanchez de Prado, 2009: 338). Asimismo, se identificó un soliferreum con empuñadura del tipo D de Quesada (1997: 308-313), 
dos fragmentos de puntas de lanza que no han podido asociarse a un modelo concreto y tres regatones de enmangue tubular. Entre los objetos de ajuar, se catalogaron distintos utensilios metálicos relacionados con ritos de sacrificio y banquete, entre los que se encuentran varios fragmentos de un caldero de bronce de placas remachadas (Faro, 2015: 53, figs. 39 y 44), un cuchillo de hierro de dorso curvo, un simpulum de mango vertical de hierro y cazoleta de bronce (Faro, 2015: 67, fig. 61), dos asadores de hierro (Faro, 2015: 85, figs. 85 y 87) y unas tenazas (Faro, 2015: 88-89, fig. 91). También resulta significativa la presencia de un broche de cinturón doble o "geminado" de escotaduras laterales cerradas y seis garfios, que corresponde al tipo D.III.5 de Cerdeño (1978: 286) y al tipo B4B6 de Lorrio (1997: fig. 89), así como una fíbula de pie vuelto con remate de esfera y otra con remate de disco unido al puente, del tipo 7D de Argente (1994: 83).

El enterramiento, a partir de estos materiales y de la información aportada por el registro arqueológico, puede fecharse entre la segunda mitad del s. IV y comienzos del s. III a. C. No obstante, no debemos descartar una fecha anterior para la fabricación de esta espada, que la aproximaría al momento planteado por Gustavo Jiménez. Esta posibilidad se desprende de la naturaleza de la espada, de la propia transcendencia de estos objetos que facilita su perduración en el tiempo y de la existencia constatada de una reparación.

\section{Ejemplar 44.11}

Esta espada, al igual que la anteriormente descrita, fue hallada en el interior de un rebaje o loculus excavado en el terreno natural y situado debajo del lugar elegido para colocar la urna. En su interior también depositaron el resto de las armas que formaban parte de la panoplia (Fig. 14).

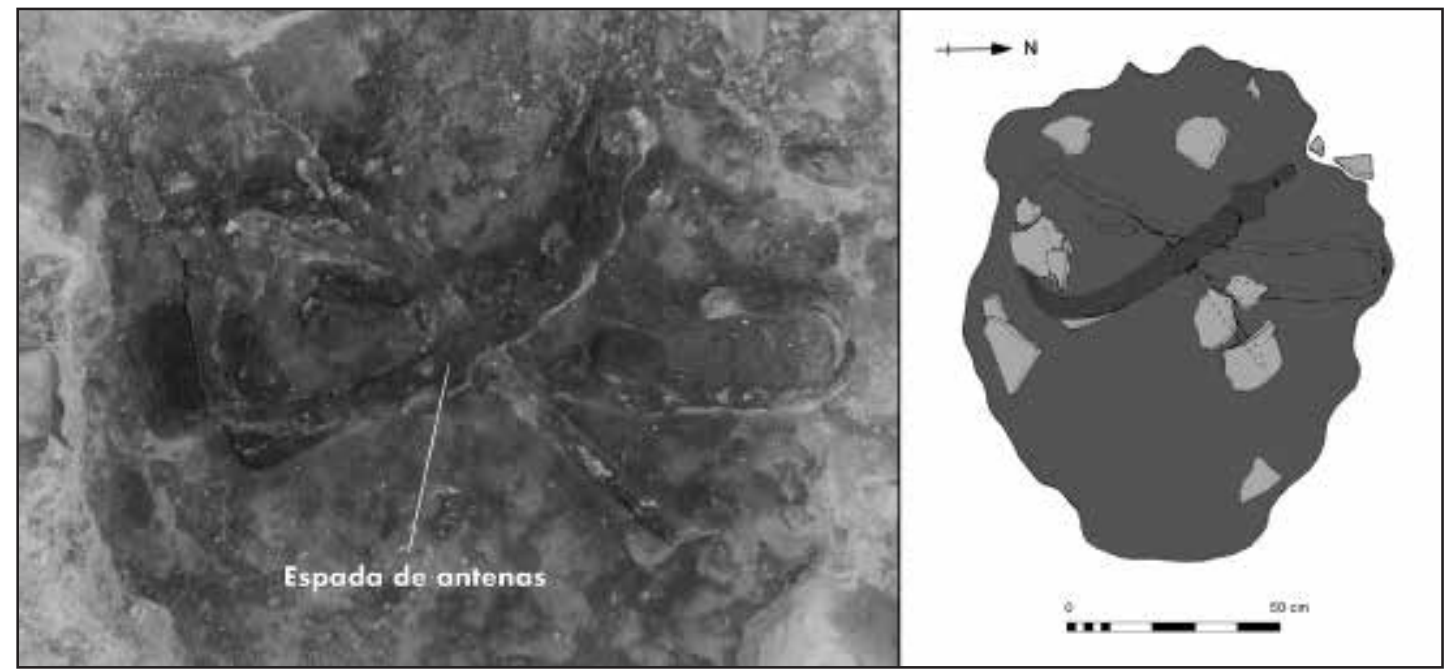

Figura 14. 44.11. Depósito de armas en el interior de un pequeño loculus. Entre las piezas amortizadas se recuperó un soliferreum y una espada de antenas tipo Etxauri/Quesada II. (Foto Gabinete Trama S. L.)

El ejemplar fue doblado de forma previa a su amortización en la tumba, aunque presenta menos alteraciones que la depositada en la e. f. 23. La única ausencia significativa son las ante- 
nas, de las que únicamente se han recuperado dos fragmentos muy deteriorados de los remates de disco, de 3,6 cm de diámetro.

La longitud máxima conservada es de $47,8 \mathrm{~cm}$. La espiga tiene $8 \mathrm{~cm}$ de largo y es de $\mathrm{sec}-$ ción cuadrada, de $0,8 \mathrm{~cm}$ de lado. Los dos cilindros troncocónicos huecos, que envolvían las cachas de materia orgánica que sujetaban la espiga, tienen $2,5 \mathrm{~cm}$ de diámetro máximo. La guarda es curva, con los gavilanes en "S". Tiene una amplitud de $6 \mathrm{~cm}$ y un desarrollo de 2,2 $\mathrm{cm}$. La hoja es estrecha y recta, de doble filo y con nervio central poco marcado. Su longitud es de $37,2 \mathrm{~cm}$ y su anchura en la parte central de $3 \mathrm{~cm}$ (Fig. 15).

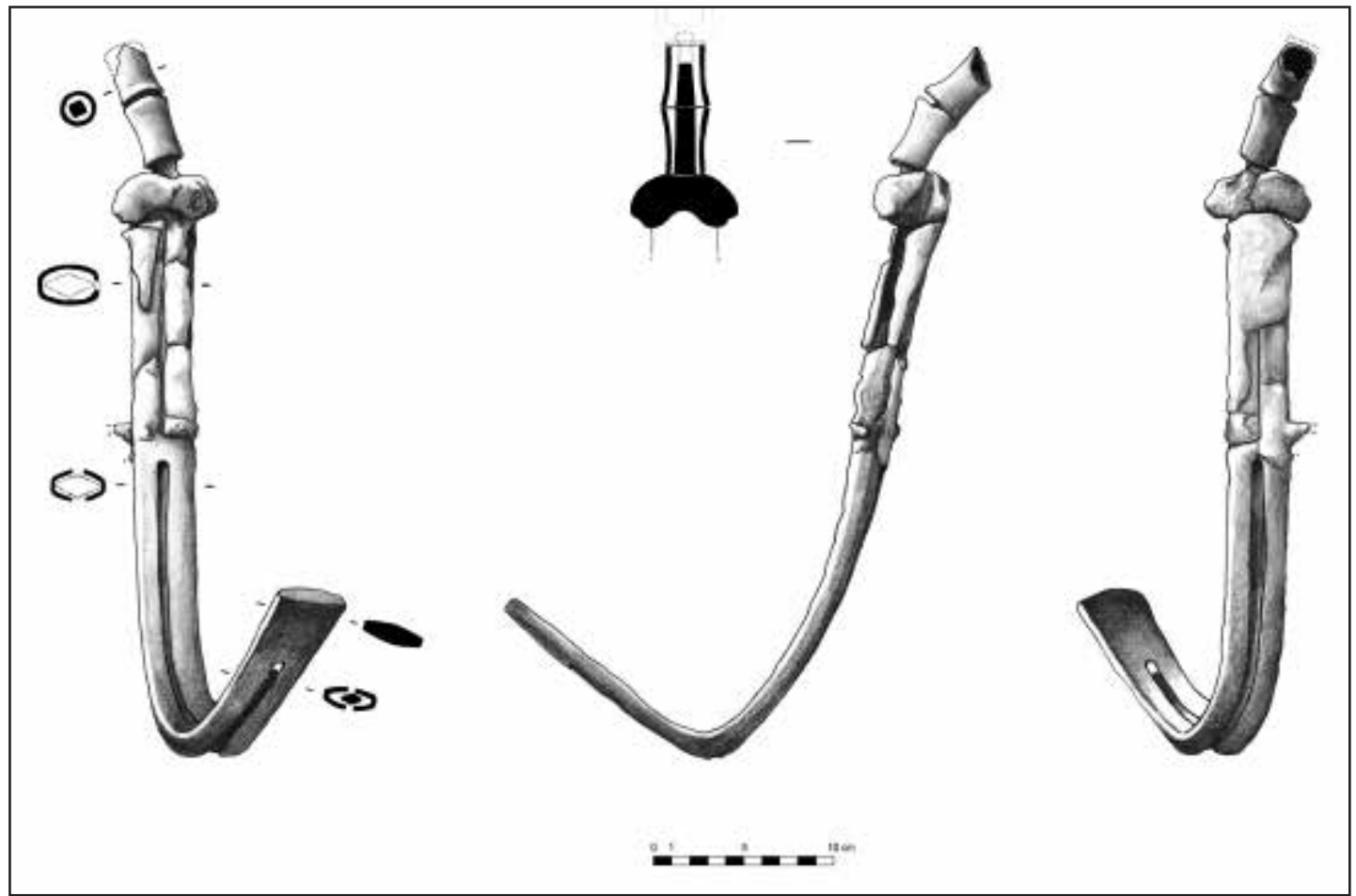

Figura 15. 44.11. Espada de antenas tipo Etxauri/Quesada II.

La vaina es enteriza, de 3,4 cm de anchura, y se encuentra fundida a la hoja. La embocadura es curva, con los hombros rectos. En su elaboración emplearon dos piezas unidas mediante soldadura que dejan en el centro, tanto en el reverso como en el anverso, una ranura longitudinal de $22 \mathrm{~cm}$ de desarrollo y $0,5 \mathrm{~cm}$ de anchura. La contera es recta y termina en horizontal (Fig. 16). Para la suspensión de la espada, la vaina debió contar en lado izquierdo con dos anclajes laterales, de los que se conserva el más alejado de la empuñadura. También se ha identificado, desprendida de su posición original, una de las anillas, de $2 \mathrm{~cm}$ de diámetro. Este sistema de suspensión es el más frecuente en las espadas de antenas tipo Etxauri/Quesada II.

La ausencia de decoración es otro de los aspectos que relaciona esta pieza con los modelos más difundidos de este tipo de espadas. En ellos, a la gradual reducción del tamaño de la hoja y de la vaina, se fue uniendo la progresiva simplificación de los motivos ornamentales, llegando a desaparecer en las vainas (García Jiménez, 2006: 44).

El ejemplar 44.11 debe incluirse entre las espadas de tipo Quesada II, a las que se atribuye una cronología situada entre los s. V - IV a. C. (Quesada, 1997a: 207). Atendiendo a sus carac- 


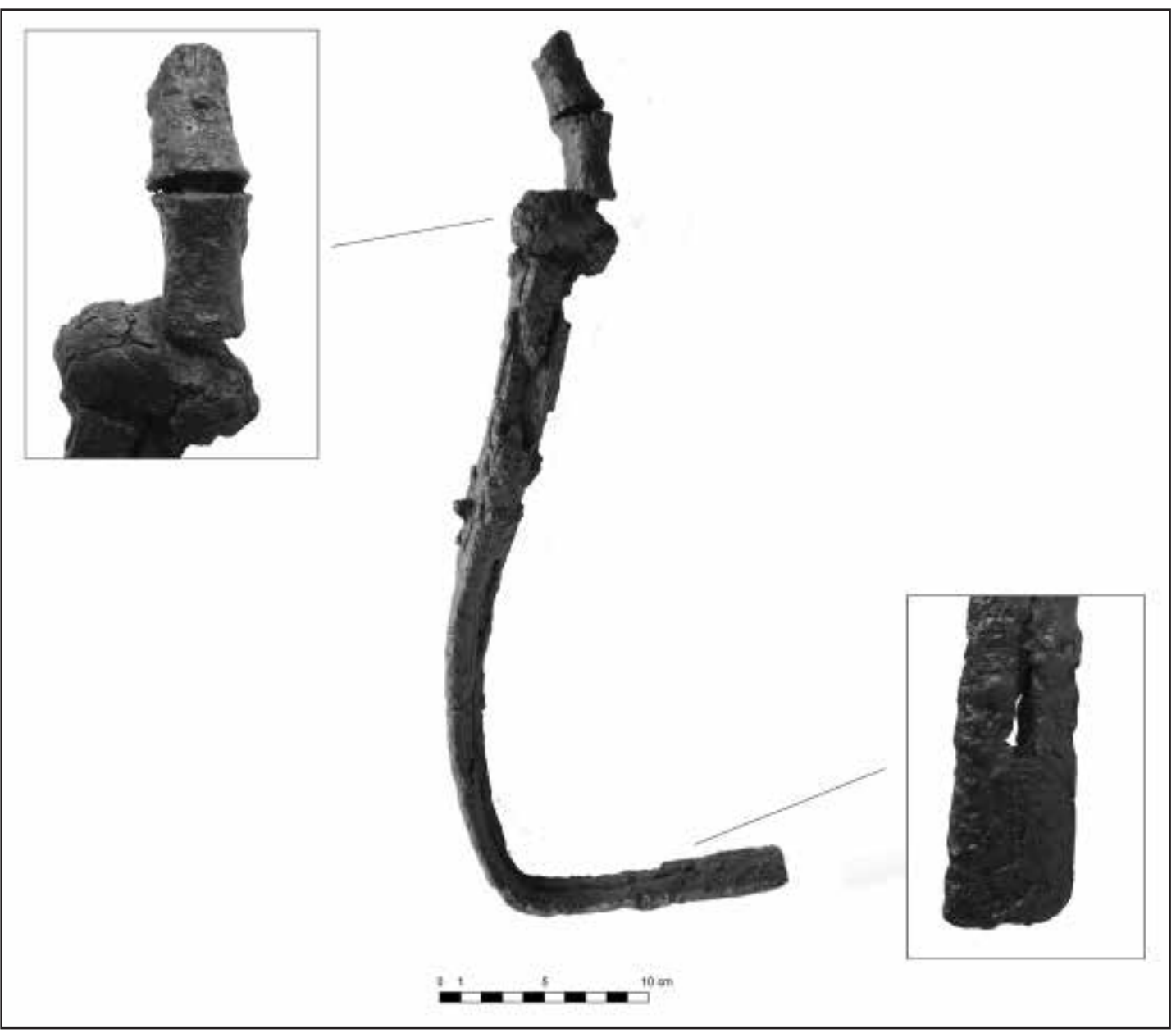

Figura 16. 44.11. Espada de antenas tipo Etxauri/Quesada II. Detalle de los cilindros de la empuñadura y del extremo de la contera. (Foto Gabinete Trama S. L.)

terísticas técnicas y tipológicas, se sitúa dentro del denominado Grupo III de la clasificación propuesta por García Jiménez, que reúnen a otras nueve espadas de similar estructura. Tres proceden de la necrópolis de El Altillo (Aguilar de Anguita, Guadalajara), dos de El Tesoro (Carabias, Guadalajara), una de La Requijada (Gormaz, Soria), una de Quintanas de Gormaz (Soria) y otras dos forman parte de la colección Guttman (Fig. 17). A esto se suma un fragmento de contera de Etxauri (Navarra), inédito hasta fechas recientes (García Jiménez, 2006: 42-44, fig. 12, 13, 14, 19 y 20). Para este conjunto, que formaría parte de la fase típica o desarrollada en la secuencia evolutiva de las espadas de tipo Etxauri/Quesada II, se ha planteado una cronología situada entre mediados/finales del s. V a. C. y el segundo/tercer cuarto del s. IV a. C. (García Jiménez, 2006: 56-57). El único matiz que aporta cierta singularidad a la pieza de El Castillo es su tamaño, algo más grande que los ejemplares anteriormente citados, con hojas con longitudes que oscilan entre los 22 y los $35 \mathrm{~cm}$.

La espada 44.11 de El Castillo formaba parte de una panoplia que también incluía un soliferreum con empuñadura del tipo A de Quesada (1997a: 308-313), un fragmento de punta de lanza que no se ha podido asociar a un modelo concreto, un regatón de enmangue tubular y un escudo de tipo caetra. De esta última pieza, se ha recuperado una anilla móvil para el sistema 


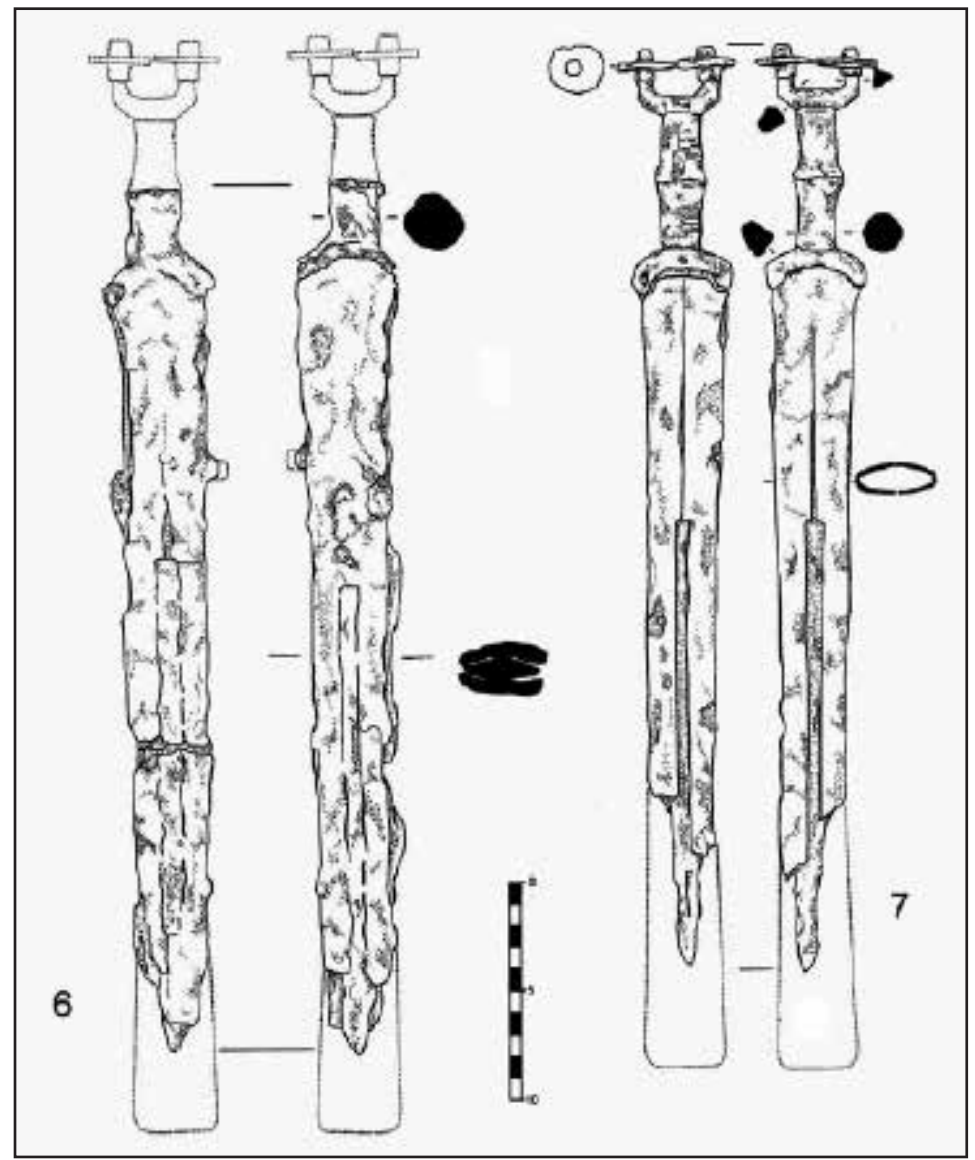

Figura 17. Espadas de antenas de tipo Etxauri/Quesada II del Grupo III de García Jiménez: 6.- Carabias; 7.- Aguilar de Anguita (García Jiménez, 2006: fig. 12).

de suspensión del correaje del tipo A de Arcobriga (Lorrio y Sanchez de Prado, 2009: 337). Entre los objetos de ajuar también se catalogó una fíbula de La Tène de apéndice caudal zoomorfo en interrogación, del tipo 8A3 de Argente (1994: 93). El enterramiento puede fecharse entre la segunda mitad del s. IV y comienzos del s. III a. C.

\section{Ejemplar 137.9}

El fragmento recuperado corresponde al extremo de una vaina enteriza de hierro y se encontró depositado en el interior del recipiente cerámico utilizado como urna cineraria. La pieza presentaba un estado de conservación muy precario. Como consecuencia de los procesos de oxidación derivados de su paso por la pira funeraria, se había fraccionado en veintiséis trozos, la mayoría de menos de $1 \mathrm{~cm}$. El hecho de encontrarse dentro de la urna y la práctica ausencia de elementos de hierro en el ajuar de esta tumba, hicieron posible su identificación y la reconstrucción parcial de su estructura. La pieza no está decorada, tiene 3,6 cm de longitud, 3,4 cm de anchura y formaba parte de una contera recta que termina en horizontal (Fig. 18). Presenta unas características y unas dimensiones muy similares a las documentadas en el ejemplar 
44.11, por este motivo la hemos incluido en este apartado, entre las espadas de tipo Quesada II y dentro del denominado grupo III de la clasificación propuesta por García Jiménez.



Figura 18. 137.9. Fragmento de contera de una espada de antenas de tipo Etxauri/Quesada II.

A diferencia del resto de espadas halladas en esta necrópolis, la contera se recuperó en una sepultura con un ajuar más austero, que no incluía otras armas ni utensilios relacionados con ritos de sacrificio y banquete. La e. f. 137 formaba parte de los túmulos de la Fase III (2 $1 / 2 \mathrm{~s}$. IV - s. III a. C.).

\section{Espadas con esquema de La Tène}

Las espadas de La Tène se caracterizan por ser generalmente largas y de hierro, con hombros curvos o arqueados, doble filo y punta más o menos prominente. Las empuñaduras se estructuran alrededor de una espiga proporcionada al tamaño de la hoja y, en la mayoría de los casos, fueron realizadas en materiales orgánicos, por lo que no suelen dejar rastro en el registro arqueológico. Las vainas son enterizas de metal, normalmente de hierro, y pueden estar decoradas (Quesada, 1997a: 243-245; García Jiménez, 2011: 161) (Fig. 19).

En el territorio peninsular las principales áreas en las que se concentra el mayor número de espadas de La Tène corresponden al Noreste y a la Meseta oriental. En el alto y medio valle del Ebro las referencias son más escasas. Tres ejemplares proceden de la localidad de Etxauri (Navarra) (Bosch Gimpera, 1921: lám. I; Castiella y Sesma, 1988-1989: 385, fig. 2); uno del túmulo 4 de la necrópolis de la Avenida de Martínez Velasco (Huesca) (Juste, 1991: 367), fechado en el s. V a. C.; otro, datado en el s. IV a. C., se localizó en la necrópolis de 


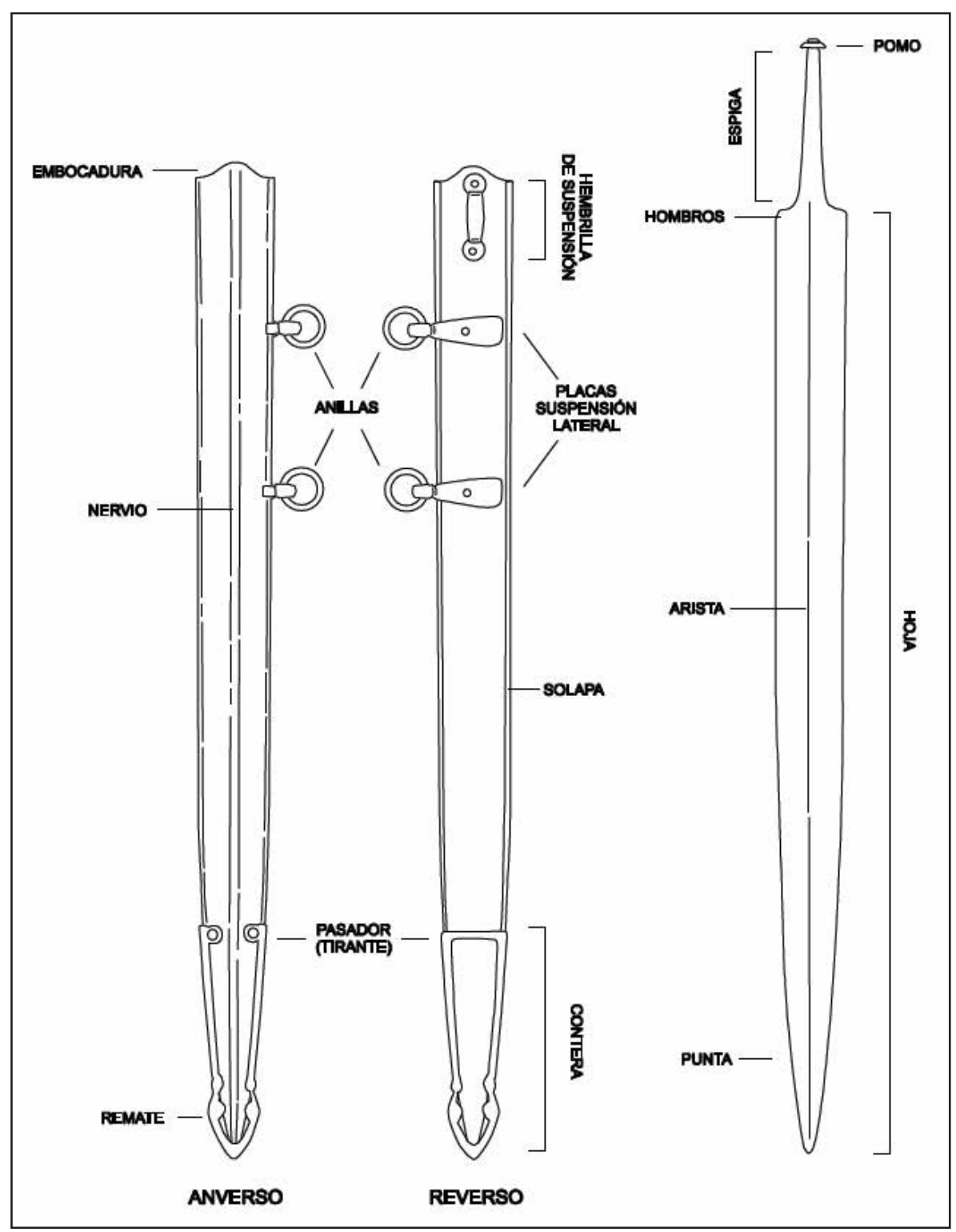

Figura 19. Partes y elementos de una espada de La Tène (según García Jiménez, 2011: fig. 18).

Busal (Uncastillo, Zaragoza) (Burillo, 1977: 52 y 57; Royo, 1980: 245 y 275); y un tercero en la necrópolis de Piñuelas (Laguardi-Biasteri, Álava) (Llanos, 1990: 140, fig. 2). En el depósito de armas de La Azucarera (Alfaro, La Rioja), en un contexto más tardío, se identificaron tres espadas de La Tène y doce gladii hispanienses (Iriarte et alii, 1996: 174-180).

En la necrópolis de El Castillo se han catalogado tres espadas de La Tène $(11.8,141.10$ y 167.7), en sepulturas correspondientes a la Fase III ( $2^{\mathrm{a}} 1 / 2$ s. IV - s. III a. C.) (Fig. 6).

La introducción y la difusión del armamento de La Tène en la península ibérica es un tema que ha sido objeto de revisión en la tesis doctoral publicada por García Jiménez (2011: 784-804). En lo referente a las espadas, la opinión generalizada de los investigadores sitúa los 
primeros ejemplares en un momento avanzado del s. IV a. C. (Cabré de Morán, 1990: 215-216; Quesada, 1997a: 259; Lorrio, 1997: 156-188). García Jiménez plantea la existencia de una fase de contacto entre la segunda mitad del s. V a. C y el primer tercio del s. IV a. C, a la que corresponden las primeras armas de La Tène documentadas en territorio peninsular, y señala cuatro focos de contacto diferenciados. Uno de estos focos, vinculado a una vía de penetración aquitana, lo sitúa en el valle medio del Ebro (García Jiménez, 2011: 841). Para la elaboración de la tesis, incluyó en su estudio los ejemplares 11.8 y 167.7 de El Castillo y los clasificó dentro de esta fase inicial o de contacto, lo que reforzaba la teoría de la mencionada vía aquitana y de un foco temprano en el valle medio del Ebro. Sin entrar a valorar este planteamiento, consideramos errónea la cronología propuesta para estas espadas. Tampoco creemos acertado atribuir un criterio general, como puede ser la inclusión de El Castillo fundamentalmente en la Fase Final o Campos de Urnas tardíos del valle medio del Ebro (500-350 a. C.) (Faro et alii, 2002-2003: 74), a dos casos particulares. Máxime si tenemos en cuenta que se trata de una necrópolis con un periodo de uso dilatado en el tiempo que al menos abarca, como ya se había señalado en anteriores publicaciones, desde el s. VI al s. III a. C. (Faro, 2002: 36).

El análisis de las características morfológicas y técnicas, como veremos a continuación, demuestra que se trata de modelos más tardíos, que pueden fecharse a finales de La Tène B o comienzos de La Tène $\mathrm{C}$. Un arco temporal más acorde a la datación relativa de las tumbas en las que fueron depositadas estas armas, pertenecientes a la Fase III (2 $2^{\mathrm{a}} 1 / 2 \mathrm{~s}$. IV - s. III a. C.), y a la cronología de los numerosos objetos que formaban parte de los ajuares.

\section{Ejemplar 11.8}

Esta espada, además de un elevado número de piezas metálicas asociadas a un carro, armas, arreos de caballo y utensilios relacionados con ritos de sacrificio y banquete, se situó junto al lateral este de la cista de adobe utilizada como cámara funeraria en la e. f. 11 (Fig. 20).

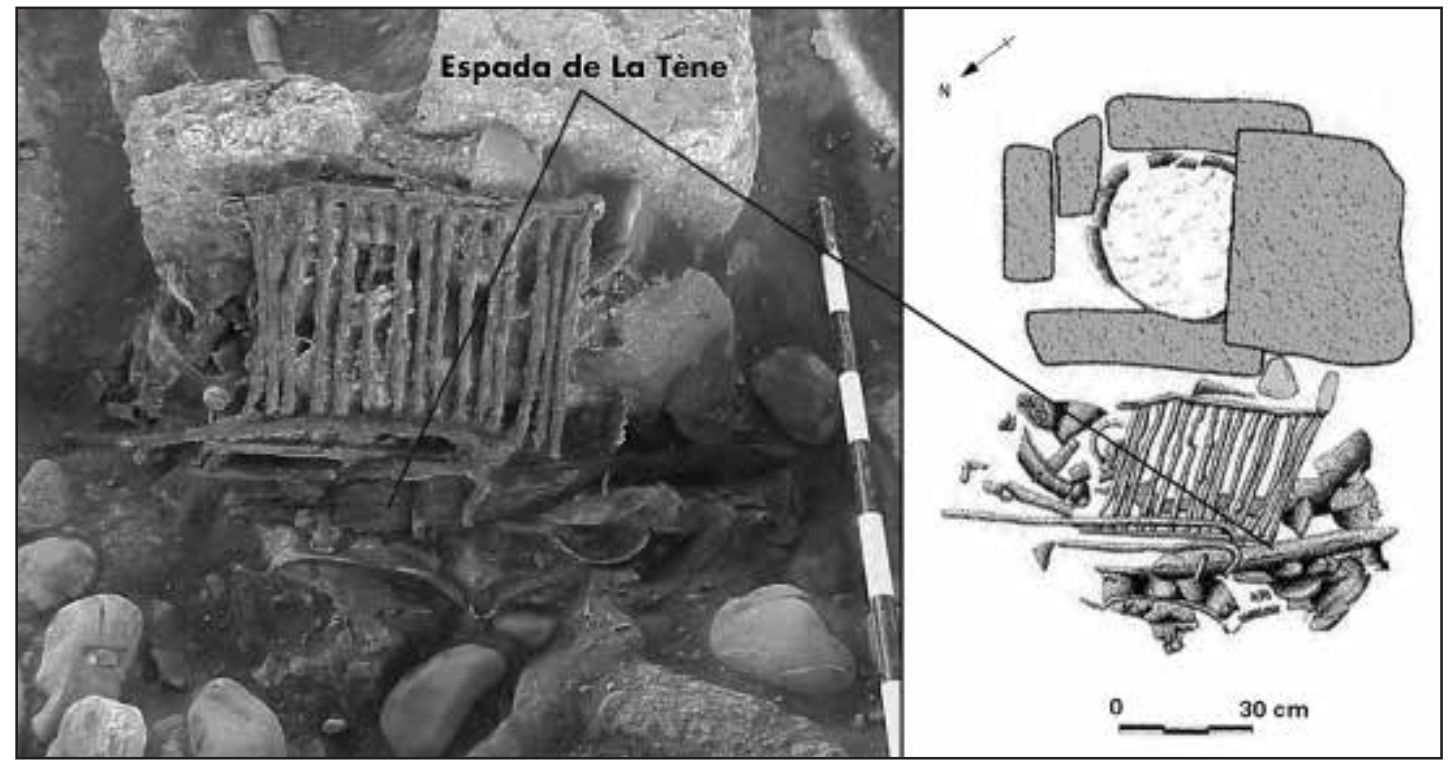

Figura 20. E.F. 11. Depósito de armas y de instrumental metálico relacionado con ritos de sacrificio y banquete. Entre las piezas amortizadas figura una espada de La Tène. (Foto Gabinete Trama S. L.) 
Este túmulo es el de mayores dimensiones de todos los excavados en la Fase III ( $2^{\mathrm{a}} 1 / 2 \mathrm{~s}$. IV - $\mathrm{s}$. III a. C.) y el que presenta el ajuar cuantitativa y cualitativamente más destacado.

Este ejemplar, a diferencia de otras armas documentadas en la necrópolis, no fue plegado de forma intencionada antes de proceder a su amortización definitiva en la tumba. Una salvedad en el modo de depositar el objeto que no se trasladó a otros aspectos del ritual funerario, preservándolo de la cremación. Por el contrario, la espada presenta signos evidentes de los efectos derivados de la exposición al fuego de la pira. A la ausencia habitual de la empuñadura, por estar realizada con materiales orgánicos, se une el deficiente estado de conservación de la vaina, de la que únicamente se mantienen algunos fragmentos adheridos al anverso de la hoja. No se ha recuperado la contera ni se ha podido obtener datos sobre su ensamblaje. Del sistema de suspensión, únicamente se ha identificado una de las tiras horizontales para un anclaje de anillas

La longitud máxima conservada de la pieza es de 70,7 cm. La espiga tiene $12 \mathrm{~cm}$ de largo, es de sección cuadrada de 1,3 cm de lado y remata en una especie de botón. La hoja cuenta con dos filos semiparalelos y sección a cuatro mesas con las aristas muy poco marcadas, que tienden hacia una sección lenticular. Su longitud es de 58,7 cm y su anchura en la parte central de

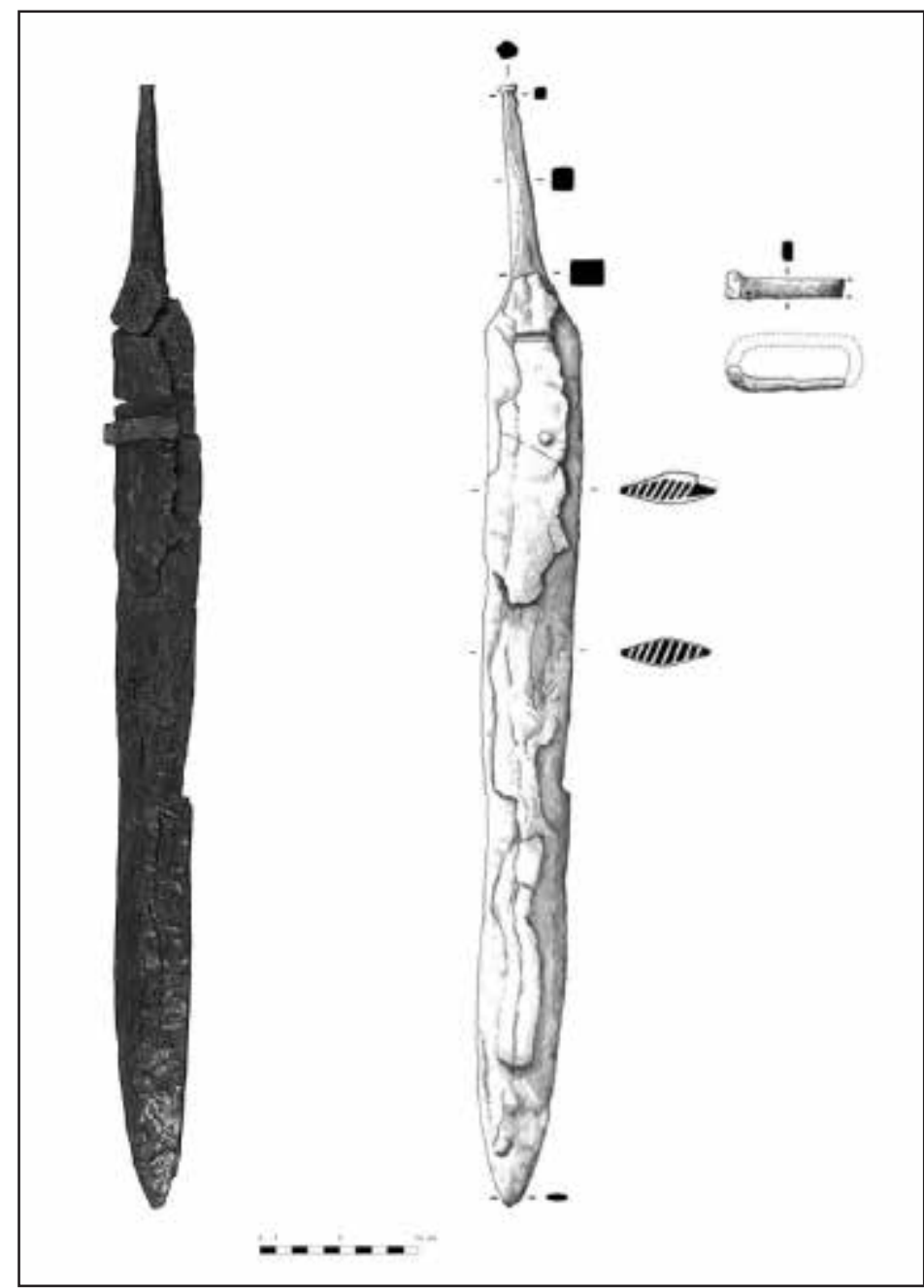

Figura 21. 11.8. Espada de La Tène. (Foto Gabinete Trama S. L.) 
$5,6 \mathrm{~cm}$. Los hombros son altos y caídos, con un desarrollo de $3 \mathrm{~cm}$. La punta es ancha y corta y los valores de la carena son netamente inferiores al 20\% de su hoja (Fig. 21).

La vaina es enteriza, consta de dos finas placas de hierro que, a consecuencia de la cremación, en parte se desprendieron y en parte quedaron fundidas a la hoja. Únicamente se han recuperado en su posición original algunos fragmentos adheridos en el anverso. Por la disposición de los hombros y los restos identificados en el tercio superior, la embocadura debió ser alta. También se recuperó, cerca del extremo proximal, un fragmento de una placa, posiblemente de tipo envolvente, que formaba parte de la suspensión lateral. Este sistema es el más extendido en las vainas peninsulares y, en general, en todo el ámbito mediterráneo. Investigadores como Quesada descartan consideraciones de índole táctica y lo relacionan con diferentes tradiciones culturales (Quesada, 1997a: 252).

En el estudio realizado por García Jiménez sobre las espadas de La Tène peninsulares incluye este ejemplar en su tipo A.1, entre los modelos correspondientes a La Tène A. Le atribuye una cronología situada entre la segunda mitad del s. V a. C. y el primer tercio del s. IV a. C. (García Jiménez, 2011: 236-237, 379-380) y señala como referentes los ejemplares del túmulo 4 de la Avenida de Martínez de Velasco (Huesca) (Juste, 1991: 367) y de la sepultura 54 de El Cigarralejo (Mula, Murcia) (Cuadrado, 1987: fig. 59). Sin embargo, del análisis morfotécnico de la pieza de El Castillo se extraen datos, algunos de ellos señalados por el propio García Jiménez (2011: 236), que contradicen esta clasificación y que la aproximan a los modelos fechados a finales de La Tène $\mathrm{B}$ o comienzos de La Tène $\mathrm{C}$. La forma de la hoja, ancha $(5,6 \mathrm{~cm})$ y con punta recia, contrasta con el módulo de las espadas de La Tène A, más estrechas (con valores máximos que suelen situarse entre 3 y $4 \mathrm{~cm}$ ) y apuntadas (Quesada, 1997a: 247; García Jiménez, 2011: 171). La sección, de tendencia lenticular, tampoco concuerda con la que habitualmente define a los ejemplares más antiguos, con nervio marcado o a cuatro mesas con filos a doble bisel. Por el contrario, sí es la más frecuente en La Tène C, sobre todo tras la desaparición de los nervios a comienzos del s. III a. C. (Lejars, 2003: 24; García Jiménez, 2011: 170). Los hombros caídos con valores que superan ampliamente los 1,5 cm tampoco son representativos de las primeras producciones y también siguen los patrones de La Tène C, indicando el uso de empuñaduras y de embocaduras altas (García Jiménez, 2011: 270).

La espada 11.8 se identifica, por tanto, con el tipo VII C de Quesada (1997a: 255) y presenta afinidades con algunos de los ejemplares del grupo B.1.3 y sobre todo con el grupo C.1.1 de García Jiménez (2011: 265, 271-272, fig. 47 y 50) (Fig. 22), para el que se ha propuesto una cronología centrada en los s. III - II a. C. (García Jiménez, 2011:379 y 384). La mayoría de piezas de estos modelos se documentan en la Meseta oriental, en necrópolis como Arcobriga (Monreal de Ariza, Zaragoza), Quintanas de Górmaz (Soria), Viñas de Portuguí (Osma, Soria), Las Horazas (El Atance, Guadalajara), o Los Llanos (La Olmeda de Jadraque, Guadalajara) (García Jiménez, 2011: fig. 292-295). Los ejemplares más cercanos proceden del depósito de Etxauri (Navarra) (Bosch Gimpera, 1921: lám. I; Castiella y Sesma, 1988-1989: fig. 2) y de La Azucarera (Alfaro, La Rioja) (Iriarte et alii, 1996), en este último caso hallados en un contexto más tardío.

El ejemplar de El Castillo presenta algunas singularidades, como la sección cuadrada de la espiga. En este tipo de espadas es más frecuente la sección rectangular, pero también encontramos algunas piezas con esa misma tendencia, como sucede en una de las recuperadas en la necrópolis de Viñas de Portuguí (Osma, Soria), en otra de Las Horazas (El Atance, Guadalajara) (García Jiménez, 2011: fig. 292 y 295) o en una tercera que procede de La Azucarera (Alfaro, La Rioja) (Iriarte et alii, 1996: fig. 4). Otra de las particularidades es el tamaño de la hoja, 58,7 $\mathrm{cm}$, que no alcanza los valores más repetidos para estos modelos, que se sitúan entre $60-65 \mathrm{~cm}$. Ejemplos similares, con longitudes de $57 \mathrm{~cm}$, los encontramos en las necrópolis celtibéricas 


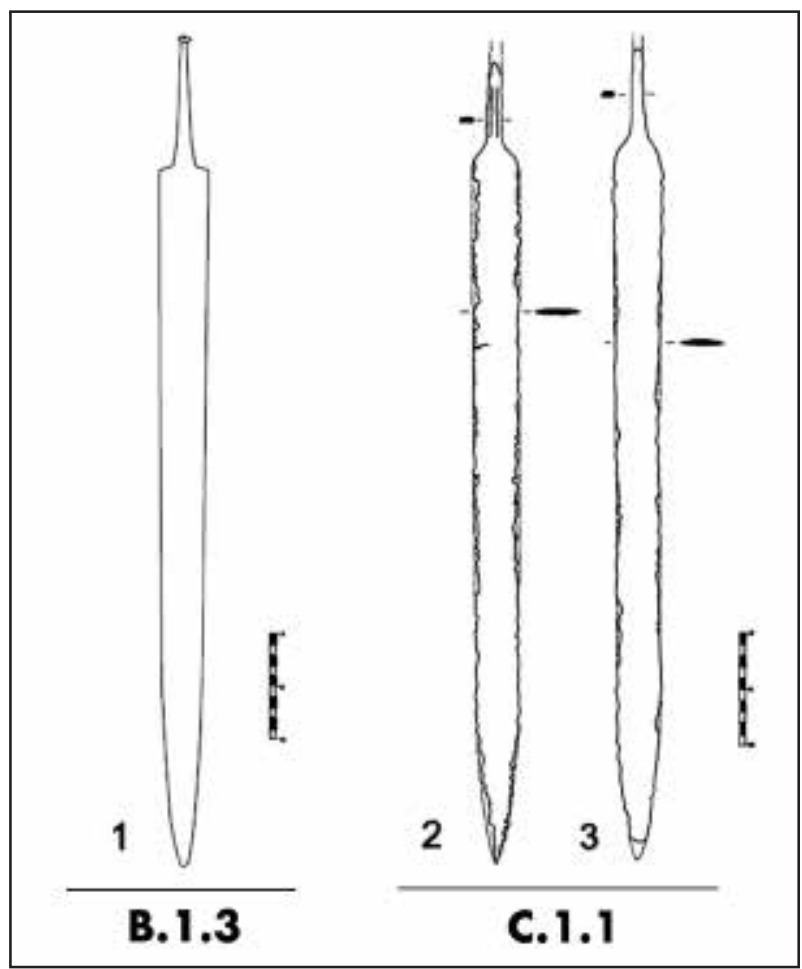

Figura 22. Espadas de La Tène según García Jiménez. Grupo B.1.3: 1.- Osma, sep. 14. Grupo C.1.1.: 2.- Arcobriga; 3.- Fuente Tojar (García Jiménez, 2011: fig. 49 y 50). de Viñas de Portuguí (Osma, Soria) y Las Horazas (El Atance, Guadalajara), así como en el cementerio vettón de La Osera (Chamartín de la Sierra, Ávila) (García Jiménez, 2011: fig. 292 y 295).

La trascendencia social del individuo enterrado en la e. f. 11 de El Castillo, propietario de esta espada, se ve reflejada en el uso de un carro funerario ceremonial para su traslado hasta la necrópolis y su depósito en la pira funeraria. En el interior de la tumba se recuperaron numerosas piezas metálicas (grapas, charnelas, etc.) de considerables dimensiones que formaban parte del atalaje del citado carro, así como tres arreos de caballo con brazos iguales articulados de sección cuadrangular, del tipo D de Quesada (2005: fig. 21), y diversos elementos de ensamblaje. Asimismo, en el interior de la tumba fue amortizada una panoplia compleja, que presentaba la singularidad de contar con dos espadas, además del ejemplar de La Tène se recuperó una falcata, una pieza que también ha sido objeto del presente estudio. Junto a ellas se catalogó una punta de lanza del tipo 2c de Quesada (1997a: 363), un regatón de enmangue tubular y distintos elementos metálicos que formaron parte de, al menos, dos escudos de tipo caetra.

Entre los objetos hallados en esta sepultura, destaca el uso como contenedor cinerario de un tipo de copa de grandes dimensiones de perfil crateriforme (Faro, 2015: 41, fig. 22). Un modelo que hasta la fecha no se había documentado en el valle medio del Ebro, que se vincula únicamente a túmulos de la Fase III de El Castillo y que fue utilizado como urna en los enterramientos que presentaban los ajuares más destacados y con un mayor número de armas y de utensilios metálicos relacionados con ritos de sacrificio y banquete. En el caso de la e. f. 11, al margen de la panoplia descrita, se catalogaron dos hachas de hierro (Faro, 2015: 50, fig. 37), un caldero de bronce elaborado en una sola pieza (Faro, 2015: 54, fig. 4), dos simpula con mango vertical de hierro y cazoleta de bronce (Faro, 2015: 67, figs. 59 y 61), un rallador (Faro, 2015: 69-70, figs. 62 y 63), un gancho de carne (Faro, 2015: 71-73, figs. 64 y 67), una parrilla (Faro, 2015: 78, figs. 75 y 77), dos morillos de hierro del tipo E2 de Almagro-Lorrio (Faro, 2015: 80-82, figs. 78-80) $)^{2}$ y un asador de bronce (Faro, 2015: 83-87, figs. 81 y 87).

Por último, también se identificaron siete fíbulas. Un ejemplar de pie vuelto con remate de disco, que se corresponde con el tipo 7C de Argente (1994: 80) y presenta la particularidad de

2 Autores como Almagro-Gorbea y Lorrio, en un estudio de conjunto sobre morillos rituales de Hispania, han analizado las piezas halladas en la e. f. 11 y les han atribuido una cronología baja, situada entre el s. IV e inicios del s. III a. C.; cronología que concuerda con la que presentan otros objetos de muy diversa naturaleza amortizados en esta tumba y con la fecha propuesta para este enterramiento (Almagro-Gorbea y Lorrio, 2011: 96-100, figs. 44 y 45). 
contar con un resorte de charnela de bisagra; uno de pie vuelto con remate de torre, del tipo 8A2 de Argente (1994: 88); uno de apéndice caudal de balaustre inclinado hacia el puente, del tipo 8A1 de Argente (1994: 86-88); y los cuatro restantes de apéndice caudal zoomorfo en interrogación, del tipo 8A3 de Argente (1994: 93).

\section{Ejemplar 141.10}

Esta espada, al igual que los ejemplares $23.6,44.11$ y 167.7 , fue hallada en el interior de un rebaje o loculus excavado en el terreno natural y ubicado muy cerca de la cista de adobe que contenía la urna cineraria (Fig. 23).

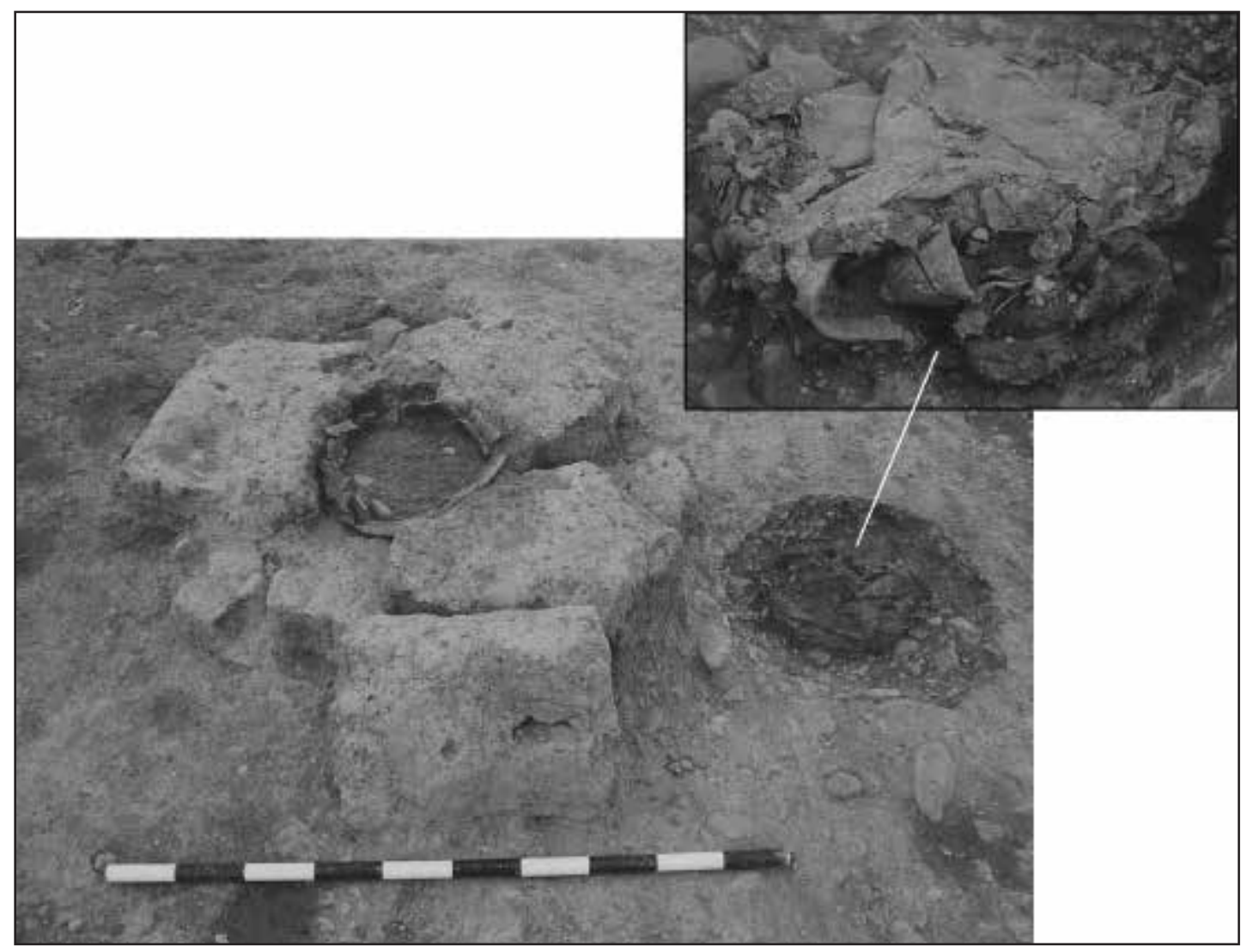

Figura 23. E.F. 141. Cista de adobe con la urna y, junto a ella, pequeño loculus en el que depositaron las armas.

La pieza fue doblada en repetidas ocasiones de forma previa a su amortización en la tumba e introducida en el interior de un casco de bronce, al igual que otras armas y distintos elementos metálicos relacionados con la indumentaria y con ritos de sacrificio y banquete. Al finalizar la cremación, todos estos objetos quedaron completamente fundidos al casco que, a su vez, acabó aplastado y deformado. En el transcurso de las labores de restauración se descartó cualquier intento de extraer y separar las piezas depositadas dentro del casco, por el alto riesgo de destrucción que entrañaba este proceso. Por este motivo, la información de la que disponemos 
es muy restringida, se limita a los datos que se han podido obtener de un tramo de la hoja que asoma hacia el exterior del casco (Fig. 24).

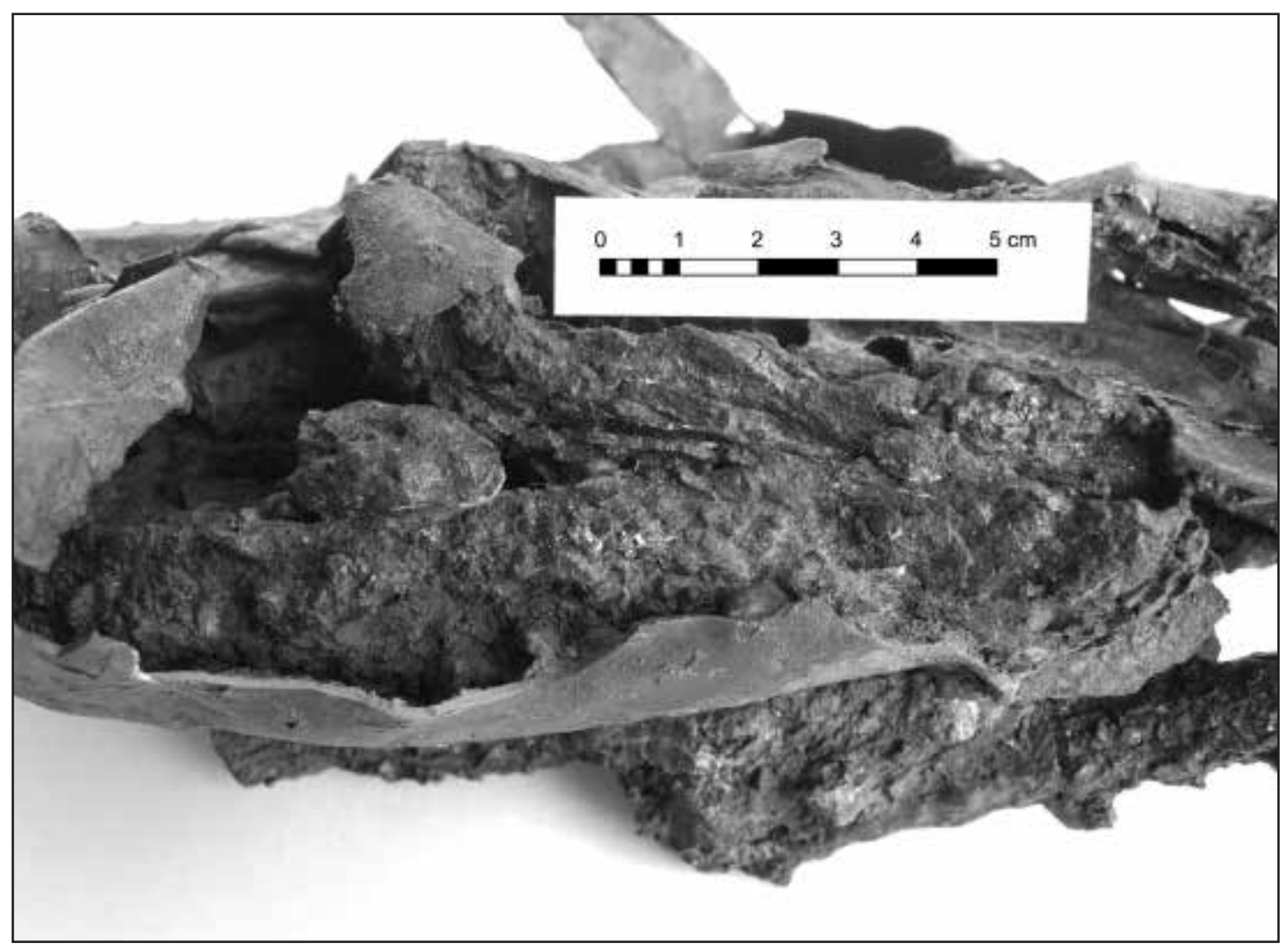

Figura 24. 141.10. Espada de La Tène plegada y depositada en el interior de un casco de bronce. (Foto Gabinete Trama S. L.)

La espada tiene hoja de doble filo, con sección a cuatro mesas y una anchura que en su parte central podría oscilar entre los 2,8 y los $3 \mathrm{~cm}$. El tramo visible tiene $54 \mathrm{~cm}$ de longitud, sin que se haya podido documentar ninguno de sus extremos (Fig. 25). También se aprecian algunos restos de la vaina, elaborada en una fina placa de hierro.

Los aspectos morfológicos y tecnológicos registrados permiten clasificar este ejemplar como espada de La Tène, aunque son insuficientes para establecer mayores precisiones tipológicas.

La pieza formaba parte de una panoplia compleja, que incluía un casco hemisférico de bronce, un soliferreum con empuñadura del tipo D de Quesada (1997a: 308-313) y un escudo de tipo caetra. De esta última pieza, se ha recuperado una anilla móvil para el sistema de suspensión del correaje del tipo A de Arcobriga (Lorrio y Sanchez de Prado, 2009: 337). Junto a estas armas se identificaron utensilios metálicos relacionados con ritos de sacrificio y banquete, en concreto un cuchillo de hierro de dorso curvo (Faro, 2015: 45) y un asador de bronce (Faro, 2015: 84, figs. 84 y 87).

En este enterramiento, al igual que sucediera en la e. f. 11, utilizaron como contenedor cinerario una copa de grandes dimensiones de perfil crateriforme. Asimismo, entre las piezas 


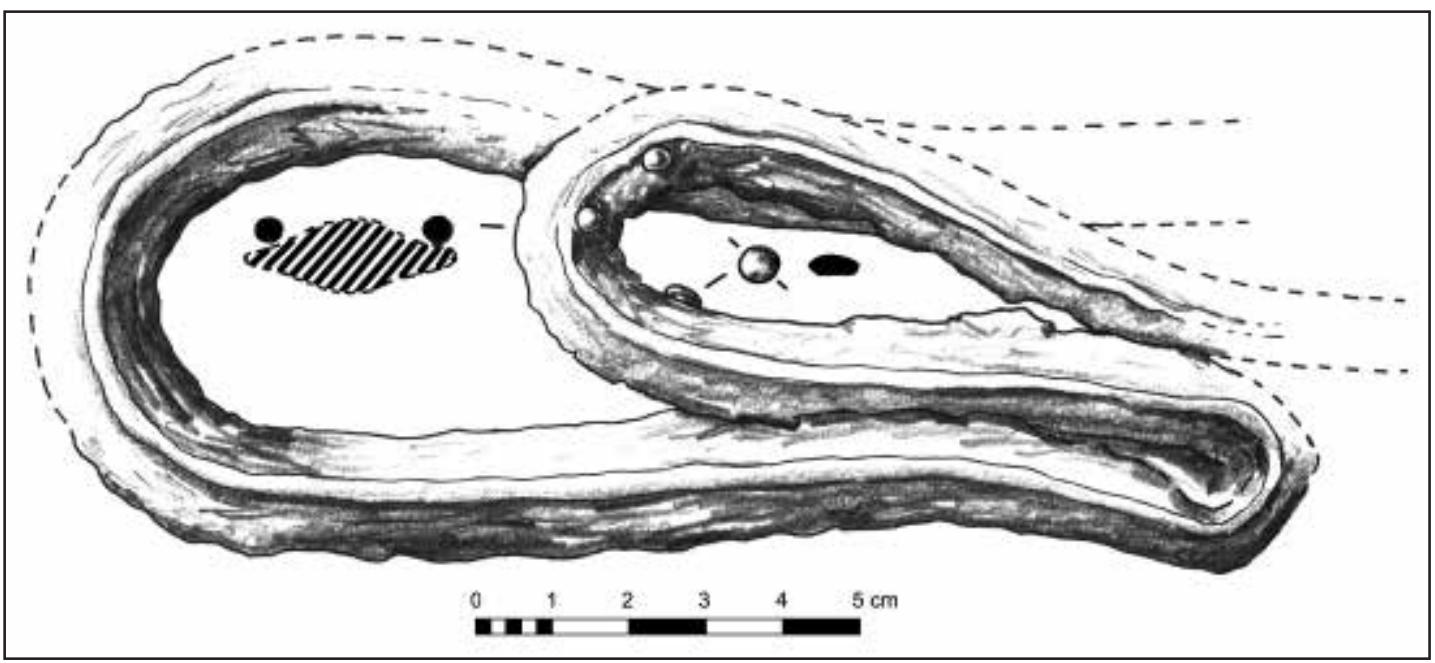

Figura 25. 141.10. Espada de La Tène.

que formaban parte del servicio cerámico se catalogó un vaso trípode decorado con motivos incisos a peine (Faro, 2015: 41), presenta similitudes con la forma VI, variante VI.5, de Las Ruedas (Sanz Mínguez, 1997: 234-235, fig. 200). Por último, entre los objetos relacionados con la indumentaria, se recuperó una fíbula de apéndice caudal zoomorfo en interrogación, del tipo 8A3 de Argente (1994: 93). La cronología relativa de esta tumba se ha situado entre finales del s. IV y la primera mitad del s. III a. C.

\section{Ejemplar 167.7}

Esta espada, como en el caso anterior, fue hallada en el interior de un rebaje o loculus excavado en el terreno natural. En esta ocasión, el rebaje corresponde a la negativa abierta para la ubicación de una estela de piedra caliza. Junto a la base de la estela depositaron las armas del individuo enterrado, que incluían un escudo, dos puntas de lanza, dos regatones, un casco de bronce y la mencionada espada de La Tène (Fig. 26). El escudo respondía al modelo de tipo caetra y se ha recuperado el tachón circular de hierro que se fijaba en el eje central del cuerpo de madera, así como una de las anillas del sistema de suspensión del correaje del tipo A de Arcobriga (Lorrio y Sanchez de Prado, 2009: 337). Una de las puntas de lanza se identifica con el tipo 2c de Quesada (1997a: 363), de la otra únicamente se ha recuperado un fragmento que no se ha podido asociar a un modelo concreto. Los regatones presentan enmangue tubular. El casco es hemisférico, presenta decoración geométrica de acanaladuras en bandas paralelas que dejan líneas en resalte y cuenta con elementos aplicados a cada lado de la calota, en este caso cuernos metálicos ${ }^{3}$. La cronología relativa de esta tumba, a partir de sus relaciones estratigráficas y de la naturaleza de las armas depositadas en su interior, se ha situado en el s. III a. C.

3 El casco se encontró aplastado y muy deformado. Pese a ello, durante el proceso de restauración, catalogación y estudio de los materiales de la necrópolis de El Castillo se pudo recomponer su estructura. Parece responder a un modelo evolucionado a partir de los cascos de tipo Alpanseque-Almaluez, pero con elementos y decoraciones que también están presenten en los modelos hispano-calcídicos (Graells et alii, 2014), con los que pudo llegar a convivir. 


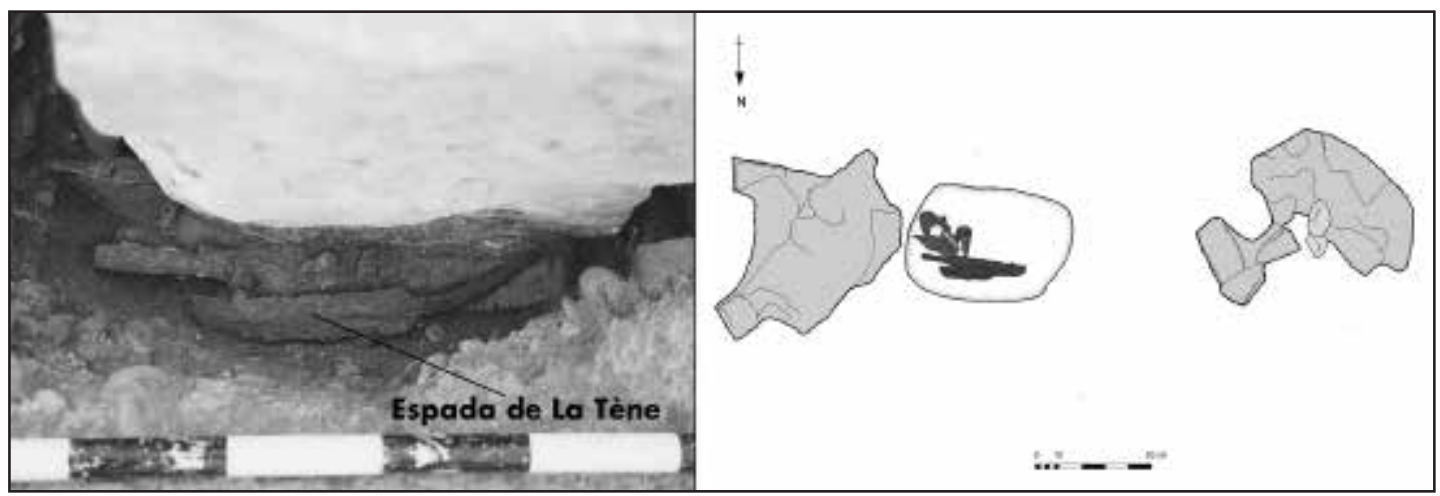

Figura 26. E.F. 167. Depósito de armas en el interior de un rebaje en el que ubicaron una estela de caliza. Entre las piezas amortizadas se recuperó una punta de lanza, un casco de bronce y una espada de La Tène. (Foto Gabinete Trama S. L.)

La espada fue doblada en "U" y presenta huellas evidentes de haber estado expuesta al ritual de cremación. Se encuentra fundida a una punta de lanza y de la vaina ha desparecido el tercio superior, incluida la embocadura, y una de las placas de suspensión para anillas laterales, aunque sí conserva la mitad inferior (Fig. 27).

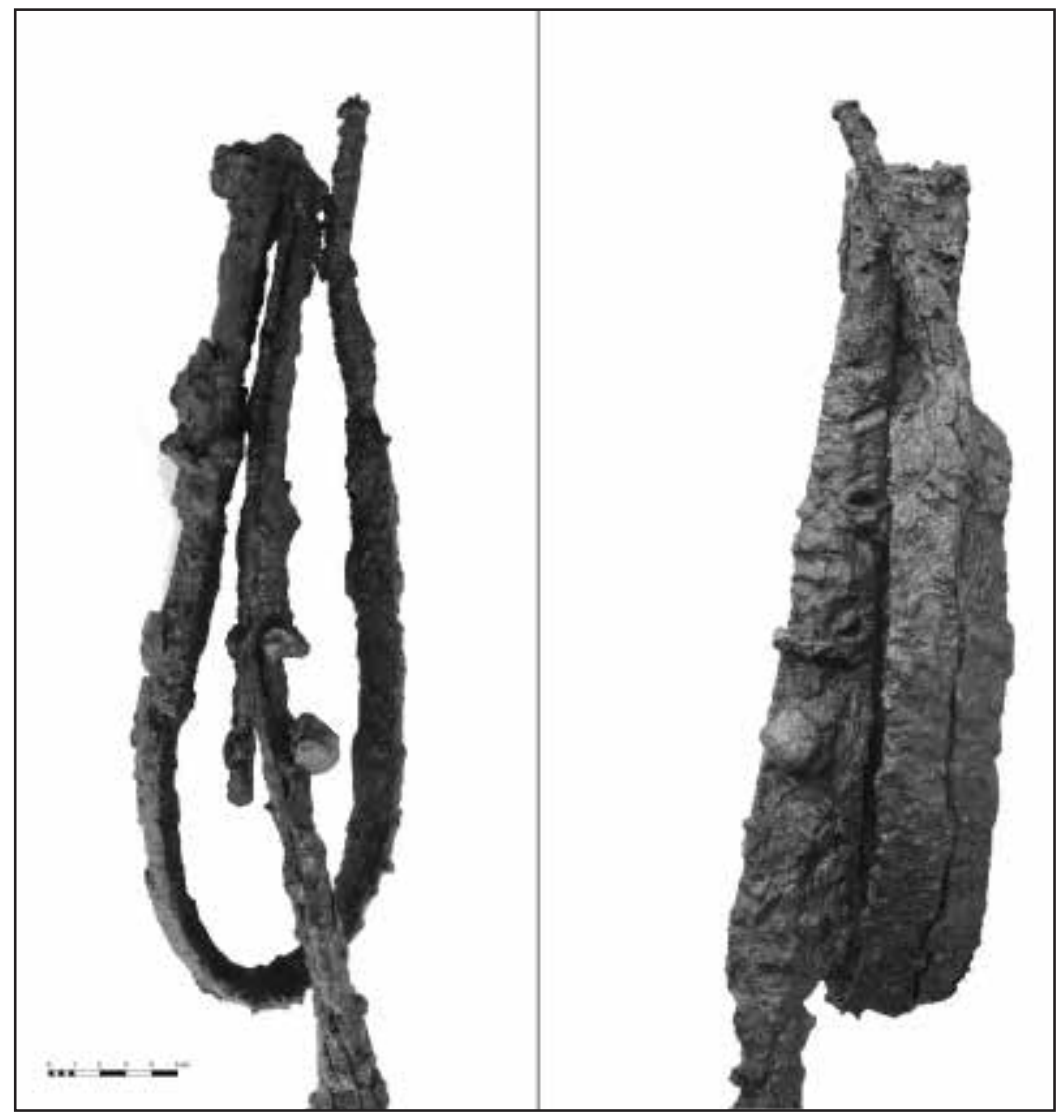

Figura 27. 167.7. Espada de La Tène. (Foto Gabinete Trama S. L.) 
La longitud máxima de la pieza es de $93 \mathrm{~cm}$. La espiga tiene $12 \mathrm{~cm}$ de largo, es de sección rectangular y remata en una especie de botón. La hoja es de doble filo y con sección a cuatro mesas. Su longitud supera los $75 \mathrm{~cm}$, aunque no se ha podido documentar su extremo distal al estar cubierto por la contera de la vaina. Su anchura, en la parte central, es de 4,2 cm. Los hombros son semirrectos o de tendencia ligeramente cóncava (Fig. 28).

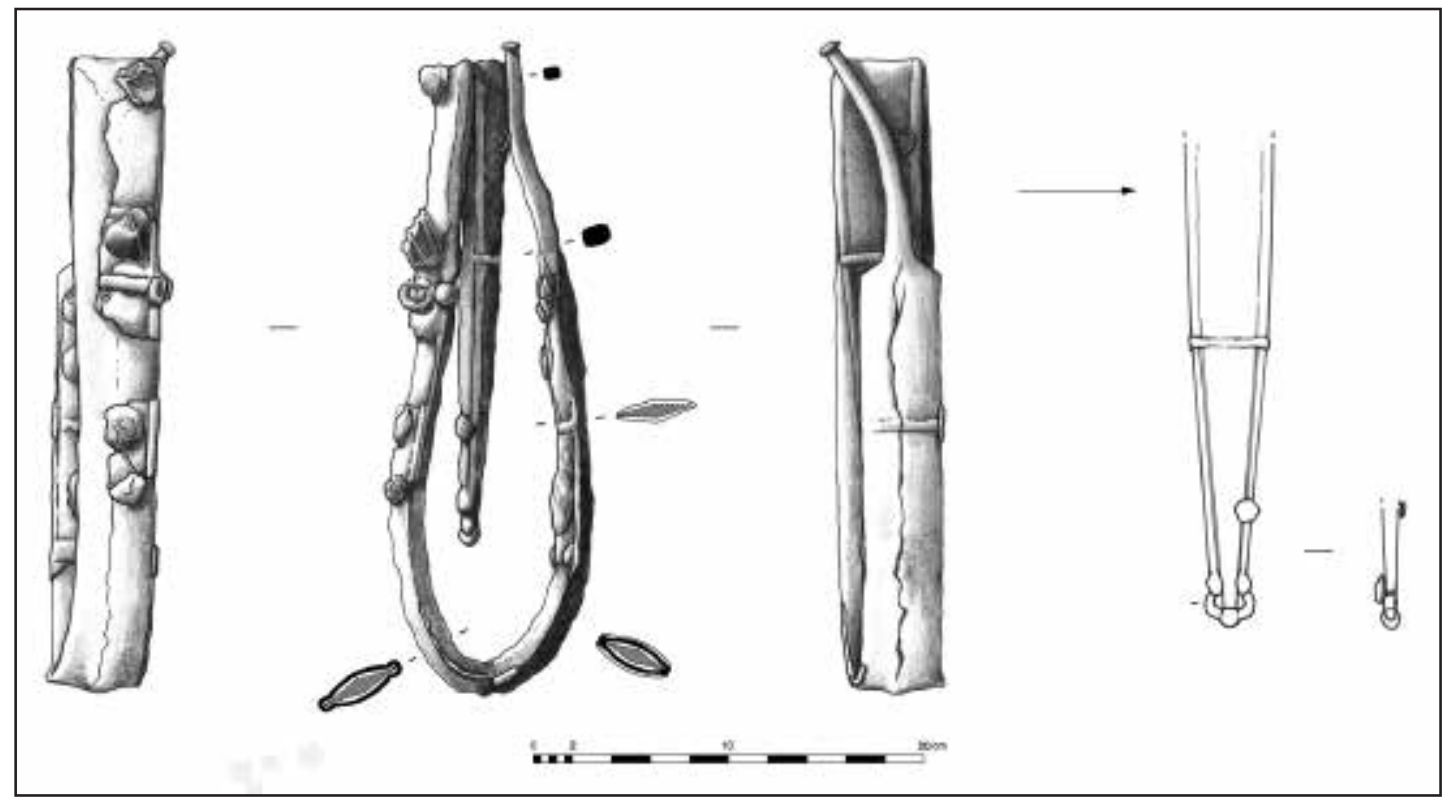

Figura 28. 167.7. Espada de La Tène.

La vaina es enteriza y está decorada con motivos geométricos en relieve. Fue elaborada a partir de dos finas placas de hierro que, a consecuencia de la cremación, quedaron fundidas a la hoja. Han mantenido su posición original varios fragmentos adheridos tanto en el anverso como en el reverso, principalmente en la mitad inferior de la pieza. El ensamblaje se realizó mediante pliegue con carriles de la placa del anverso sobre el reverso. Para el sistema de suspensión contaba con abrazaderas de tipo envolvente con anillas laterales. No se conserva la que estaría situada en su extremo proximal, la más cercana a la embocadura, y de la segunda quedan restos de la tira y parte de la anilla. A éstas se añadió una tercera en un punto muy bajo, ubicado en el tercio distal de la vaina. La contera tiene $15 \mathrm{~cm}$ de desarrollo y el remate es calado, posiblemente tridiscoidal, aunque los discos se encuentran bastante deformados por la oxidación.

En el estudio realizado por García Jiménez sobre las espadas de La Tène peninsulares incluye este ejemplar como el único representante de su tipo A.0, entre los modelos correspondientes a La Tène A. Le atribuye una cronología situada entre la segunda mitad del s. V a. C. y el primer tercio del s. IV a. C. (García Jiménez, 2011: 380) y la relaciona con algunas espadas de la región de Champagne, como la procedente de la tumba de carro de Somme-Bionne (Marne) (Stead y Rigby, 1999: inv. 1349, fig. 146 y 147). Sin embargo, del análisis morfotécnico de la pieza de El Castillo vuelven a inferirse datos, algunos de ellos nuevamente apuntados por el propio García Jiménez (2011: 235-236), que contradicen esta clasificación y que la aproximan a los modelos fechados a finales de La Tène B o comienzos de La Tène C. La longitud de la 
hoja, que supera los $75 \mathrm{~cm}$ de longitud, fue uno de los argumentos esgrimidos para vincularla a las espadas de modulo largo de La Tène A. No obstante, conviene recordar que en el ámbito centroeuropeo durante la etapa de transición entre La Tène B2 y La Tène C1 desaparecieron los ejemplares de formato más reducido en favor de otros más largos, con hojas de $65-75 \mathrm{~cm}$ (Rapin, 1999: 59-60; Lejars, 2003: 24). La anchura de 4,2 cm tampoco se corresponde con los valores más frecuentes en La Tène A, inferiores a 4 cm (Quesada, 1997a: 247). La espiga de sección rectangular, como deja constancia el propio dibujo aportado por García Jiménez (2011: fig. 251), y los hombros semirrectos, siguen los patrones habituales en las espadas de La Tène B2 y La Tène $\mathrm{C}$ 1. La sección a cuatro mesas y la inexistencia de nervio también son detalles llamativos e inusuales, como señala el propio García Jiménez (2011: 235). Aunque sin duda, el elemento que clarifica con mayor precisión la cronología de la espada es la vaina. A diferencia de los ejemplares de módulo largo de La Tène A, que preferentemente presentan la placa frontal de bronce, en este caso las dos piezas están realizadas a partir de finas láminas de hierro. Pese al deterioro causado por la cremación, en el tercio central y distal todavía se

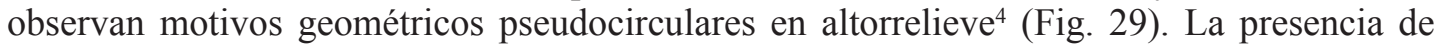

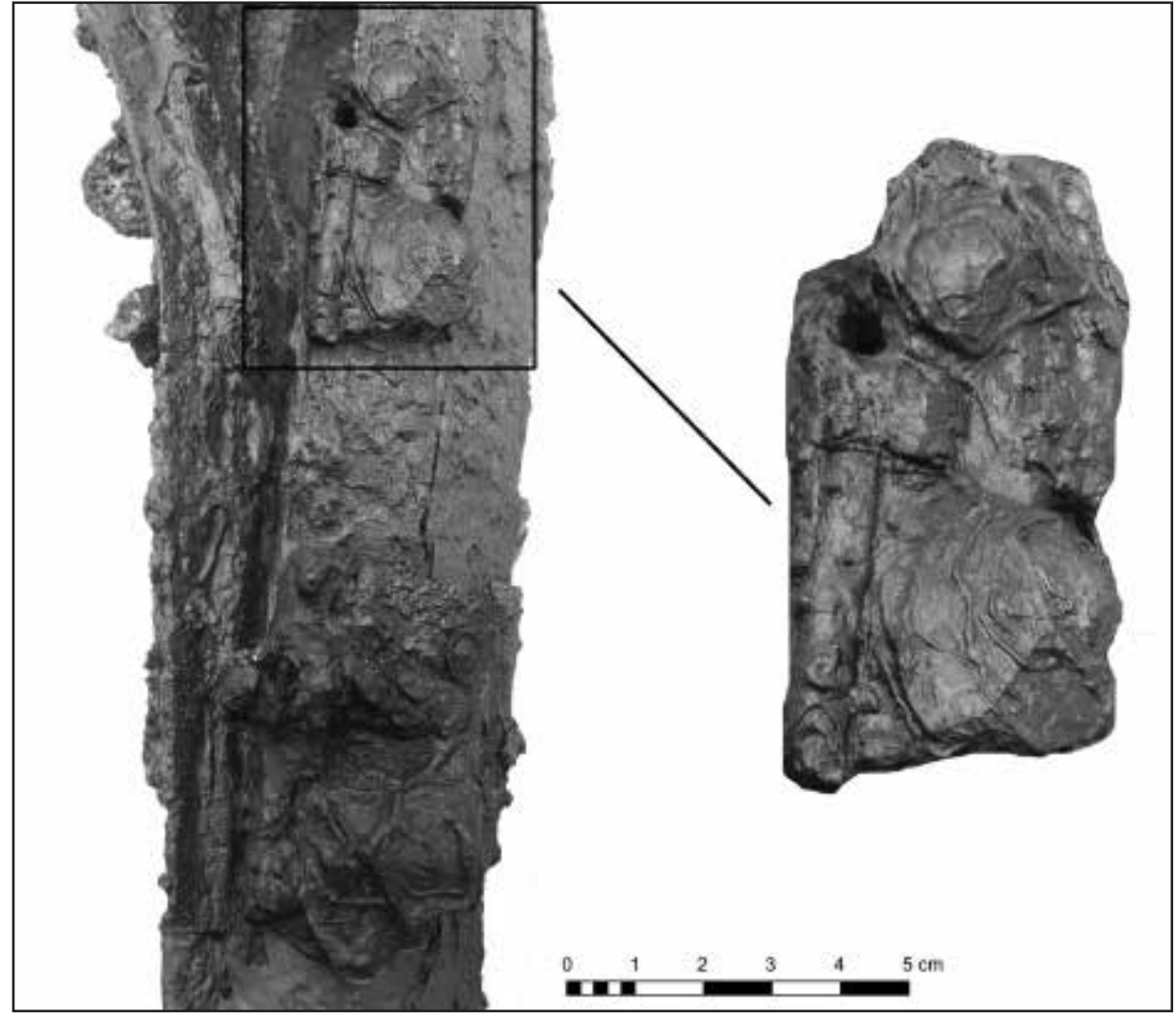

Figura 29. 167.7. Espada de La Tène. Fragmentos de la vaina con decoración de motivos geométricos pseudocirculares en altorrelieve. (Foto Gabinete Trama S. L.)

4 Este tipo de ornamentación en relieve suele situarse en la zona de la embocadura. El ejemplar de El Castillo presenta la particularidad de contar con una decoración que abarca la totalidad del anverso de la vaina. Composiciones de parecidas características, aunque de forma más esporádica, también se han documentado en distintos ejemplares de espadas de La Tène. Sirva como ejemplo la pieza hallada en Köröshegy (Balaton, Hungría), adscrita al llamado estilo de las espadas húngaras (Szabo, 1996: 545, fig. 9.4) (Fig. 30). 
estos motivos constituye, en sí misma, un testimonio suficiente para descartar la cronología que se había planteado para esta espada. La decoración en relieve, abarcando la zona de la embocadura o la totalidad del anverso de las vainas, y el uso de técnicas como el estampado y el repujado se difundió por Europa durante la etapa de transición entre La Tène B2 y La Tène $\mathrm{C} 1$, entre finales del s. IV y el s. III a. C., primero con la llegada del llamado estilo de las espadas húngaras y a continuación con el estilo plástico (Jacobsthal, 1969: 95-105; Rapin, 1999: 58; García Jiménez, 2011: 103). Estas corrientes se consideran como una evolución del estilo vegetal continuo o Waldalgesheim. La reiteración de elementos geométricos tridimensionales dio lugar a composiciones barrocas, con fuertes contrastes de luces y sombras. En último término, se interpretan como una transposición al metal de las técnicas decorativas generalmente aplicadas a la cestería y al trabajo del cuero (Lejars, 2003: 26). La cronología atribuida a estas espadas se centra sobre todo en un horizonte antiguo de La Tène C1, abarcando fundamentalmente el s. III a. C.

En la península ibérica hasta la fecha no se tiene constancia de espadas de las características de las registradas en el ejemplar 167.7 de El Castillo, aunque conviene señalar que el número de vainas de hierro conservadas es muy reducido. En Francia, ejemplares datados en contextos de finales del s. IV y principios del s. III a. C., como la vaina de la espada recuperada en una tumba de un guerrero celta en Chens-Sur-Léman (Haute-Savoie) (Landry y Blaizot, 2011: figs. 10, 11 y 15) o la hallada en la sepultura 13 de la necrópolis de Mainville (Bromeilles, Loiret) (Rapin, 1989: Pl. I y II), se consideran como precedentes de estos

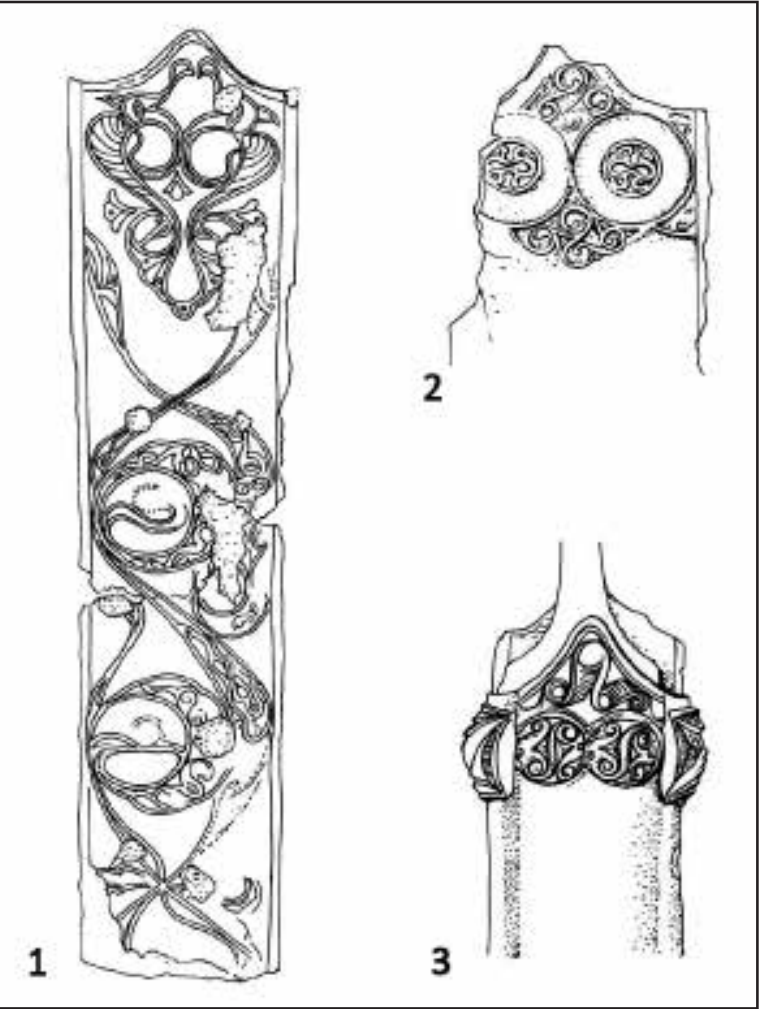

Figura 30. Vainas de espadas de La Tène con decoración de motivos geométricos circulares en altorrelieve. 1: Köröshegy (Hungría); 2 y 3: Necrópolis de Szob (Hungría) (Szabo, 1996: figs. 4.3, 4.4 y 9.4). estilos decorativos en relieve. Los motivos circulares son elementos frecuentes en las complejas composiciones que decoran las vainas de las espadas húngaras, sirvan como ejemplo algunas de las piezas procedentes de la necrópolis de Szob (Szabo, 1996: fig. 4.3 y 4.4) (Fig. $30)$.

\section{Falcata}

La falcata es una espada de hoja curva bastante corta, generalmente de menos de cincuenta centímetros de longitud, asimétrica y de anchura cambiante. Su dorso es convexo y forma una sola curva, mientras que el filo principal es cóncavo en la zona de la empuñadura y convexo hacia la punta, donde posee un doble filo, lo que la convierte en un arma capaz de asestar golpes tajantes y punzantes. La empuñadura se curva en torno a la mano y el pomo remata en una cabeza de animal, que puede ser un caballo o un ave rapaz. En la mayoría de los casos, la hoja se introducía en vainas 
de cuero con cuatro abrazaderas y anillas laterales. En ocasiones también pueden llevar botones, a veces de bronce, que servirían para unirse a un tahalí que suspendía el arma al modo mediterráneo. Los ejemplares más destacados se adornaban con finos hilos de plata mediante la técnica del damasquinado (Quesada, 1997b: 196-201).

La falcata ha sido considerada como el arma característica y más conocida de la cultura ibérica, aunque su distribución en este territorio no es homogénea. En realidad, como señala Quesada, el foco nuclear se sitúa en el área bastetano-contestana, que abarca las actuales provincias de Alicante, Murcia, Este de Albacete y el alto Guadalquivir (Quesada, 1997a: 76, fig. 10). En el resto de la costa mediterránea la cifra de falcatas es muy inferior. En el interior peninsular, el escaso número de piezas recuperadas se concentran principalmente en la Meseta oriental, en necrópolis como Quintanas de Gormaz

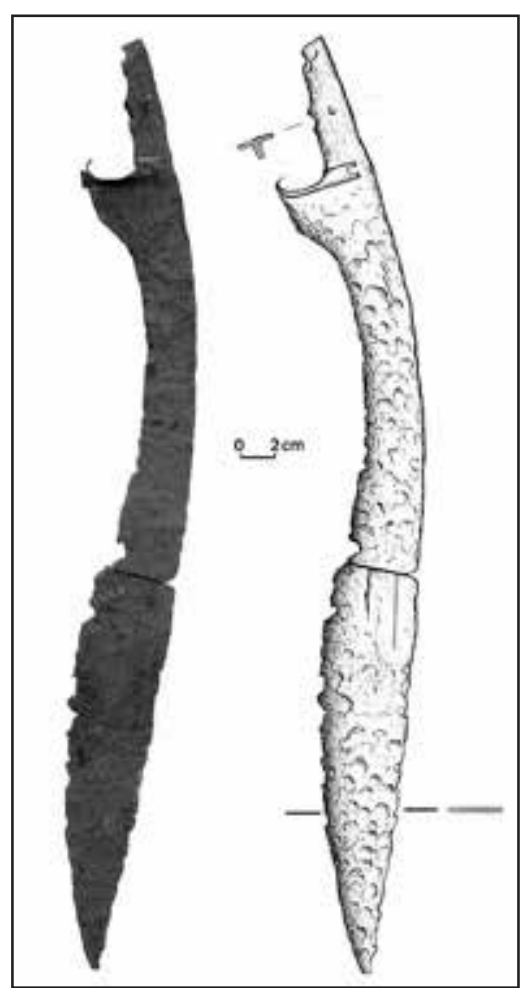

Figura 31. Falcata procedente del poblado de Peñahitero (Fitero, Navarra) (Olcoz, 2011: fig. 5). (Soria), Viñas de Portuguí (Osma, Soria), La Requijada (Gormaz, Soria) o El Tesoro (Carabias, Guadalajara) (Lorrio, 1997: 169 y 186).

El origen y la cronología de las falcatas han sido objeto de continuo debate. La postura actualmente más extendida es la que defiende una procedencia mediterránea y un proceso de adopción y transformación a partir de la machaira itálica, un tipo de arma que llegó a la península ibérica a principios del s. V a. C. o quizá algo antes (Quesada, 1997a: 159-161). Las primeras representaciones de la falcatas las encontramos en las esculturas del herôn de Obulco (Porcuna, Jaén), fechadas a comienzos del s. V a. C. (Negueruela, 1990: 303; Quesada, 1997b: 197198), sin embargo los primeros ejemplares hallados en un contexto fiable proceden de la necrópolis de Cabezo Lucero (Guardamar del Segura, Alicante) y se datan a finales del s. V a. C. o a comienzos del s. IV a. C. En el interior peninsular sólo están presentes a partir de finales del s. IV - principios del s. III a. C. (Quesada, 1997a: 81).

En la necrópolis de El Castillo se ha catalogado una falcata (11.9), en una sepultura correspondientes a la Fase III (2 ${ }^{\mathrm{a}} \frac{1}{2} \mathrm{~s}$ s. IV - s. III a. C.) (Fig. 6). Este ejemplar fue el primero documentado en el alto y medio valle del Ebro. En fechas recientes se ha publicado otra pieza procedente del yacimiento de Peñahitero (Fitero, Navarra) (Olcoz, 2011: 63-67) (Fig. 31).

\section{Ejemplar 11.9}

Esta espada, además de un elevado número de piezas metálicas asociadas a un carro, armas, arreos de caballo y utensilios relacionados con ritos de sacrificio y banquete, se localizó adosada al lateral este de la cista de adobe utilizada como cámara funeraria en la e. f. 11. Al igual que sucediera con la espada de La Tène, no fue plegada de forma intencionada, aunque sí se aprecian signos evidentes de la exposición al fuego de la pira. No conserva el extremo distal de la hoja, tampoco se han mantenido los refuerzos metálicos de la vaina de material 
perecedero y la oxidación no permite seguir el trazado de las acanaladuras ni comprobar si estuvo decorada con técnica de damasquinado.

La longitud máxima de esta falcata en origen debió ser de $53,5 \mathrm{~cm}$, de los que se han conservado $42,5 \mathrm{~cm}$. La hoja tendría una longitud de $42 \mathrm{~cm}$, con un ancho máximo de $5,5 \mathrm{~cm}$, un ancho mínimo de $4 \mathrm{~cm}$ y un ángulo axial de $80^{\circ}$. El filo dorsal tendría un desarrollo de $20 \mathrm{~cm}$. Presenta acanaladuras paralelas al dorso de la hoja, aunque sólo son visibles en un pequeño tramo del reverso. La empuñadura pertenece al tipo B de Quesada (1997a: fig. 21), con cabeza de caballo, y su longitud interior es de $8,8 \mathrm{~cm}$. La guarda basal tiene $6 \mathrm{~cm}$ de anchura y corresponde al tipo 1 de Cuadrado (1989: fig. 1). Sobre ella apoyaban las cachas metálicas de hierro, de las que se han conservado restos tanto en el anverso como en el reverso (Fig. 32).

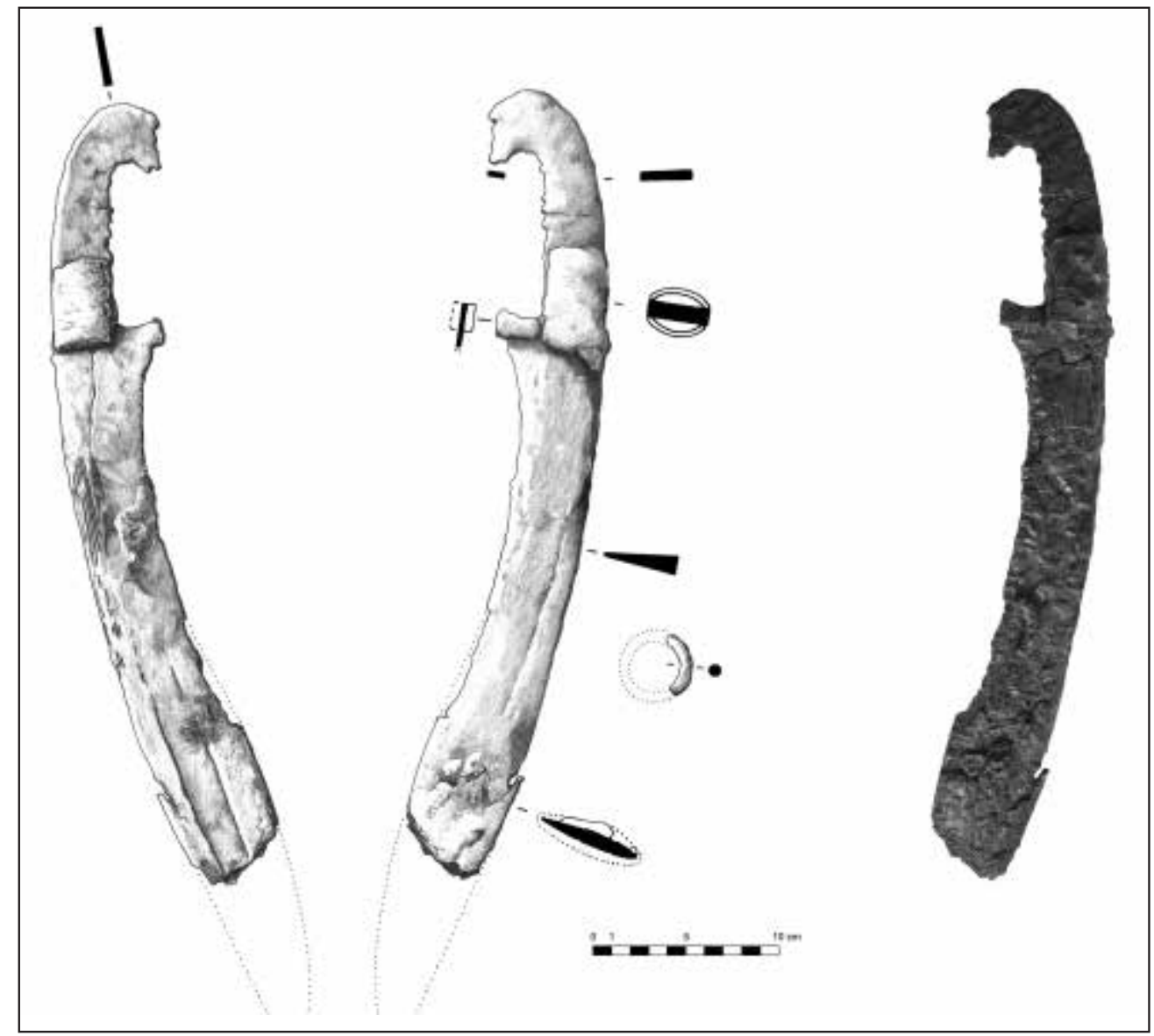

Figura 32. 11.9. Falcata. (Foto Gabinete Trama S. L.)

A falta de un análisis metalográfico exhaustivo de la pieza, no debemos descartar la posibilidad de que estuviera decorada con hilos de plata, mediante técnica de damasquinado. En el proceso de flotación del sedimento acumulado entre los metales, se recuperaron pequeños restos de plata que se habían desprendido del objeto al que acompañaban y se habían vuelto a fundir por las altas temperaturas alcanzadas durante la cremación. Otro aspecto que apunta en esta dirección es la presencia de cachas de hierro, que se considera un elemento indicativo de riqueza (Quesada, 1997a: 100). 
La atribución de una cronología precisa a partir de las características morfológicas y tecnológicas resulta complicada ya que, por el momento, no se ha podido establecer una línea evolutiva de estas armas (Quesada, 1997a: 108). Un porcentaje muy alto de las falcatas estudiadas se fechan en el s. IV a. C., siendo muy inferior el número de las que se datan en los s. III y II a. C. Pese a ello, el ejemplar de El Castillo presenta una serie de particularidades que sugieren una cronología avanzada. La hoja es corta, al igual que sucede con la mayoría de los ejemplares de la Meseta oriental, que se fechan entre finales del s. IV y comienzos del s. III a. C. Las cachas metálicas son excepcionales y también suelen corresponder a piezas tardías (Quesada, 1997a: 100). Una fecha situada en el s. III a. C. es la que resulta más probable y la que mejor se ajusta a la que presentan el resto de objetos anteriormente descritos que formaban parte del ajuar de la e. f. 11, entre los que también se encontraba la espada de La Tène (11.8).

\subsection{DistribuCión DE LAS ESPADAS EN LA NECRÓPOLIS}

El conjunto catalogado en El Castillo consta de siete ejemplares, recuperados en el interior de seis enterramientos del área intacta de la necrópolis, lo que equivale a su presencia en el 5,04\% de las tumbas (Fig. 33).



Figura 33. Plano del sector norte de la necrópolis de El Castillo con la dispersión de las espadas. 
Las espadas están ausentes en la Fase I y en la Fase II. Las piezas catalogadas fueron halladas en seis túmulos de la Fase III ( $2^{\text {a }} 1 / 2$ s. IV - s. III a. C.), lo que supone su uso en el 9,83\% de las tumbas clasificadas en este período. Depositaron un ejemplar por tumba, a excepción de la e. f. 11 que contaba con una espada de La Tène y una falcata. La presencia de dos espadas en una misma sepultura es un hecho excepcional, que suele relacionarse con la costumbre de expresar estatus por acumulación de objetos de prestigio (Quesada, 1997a: 645-646). En la península ibérica el número de enterramientos en los que se ha documentado esta circunstancia es muy reducido. Atendiendo a la naturaleza de las espadas y de los ajuares hallados en el interior de la e. f. 11, se puede establecer un paralelismo con las tumbas de caballo de la necrópolis de La Pedrera (Vallfogona de Balaguer-Térmens, Lérida). Entre los numerosos objetos metálicos hallados en dos conjuntos idénticos en función y fechados en el s. IV a. C., también amortizaron una espada de La Tène y una falcata (Graells, 2008a: 440; 2008b: 138, figs. 48 y 49).

\subsection{FunCIONALIDAD, ASOCIACIONES Y CRONOLOGÍA}

La espada tiene una finalidad práctica como arma ofensiva para el combate, capaz de asestar al enemigo golpes tajantes y/o punzantes. Pero, además de esta utilidad, la posesión de una espada también encierra una serie de connotaciones de tipo simbólico, como expresión de poder y de riqueza (Quesada, 1997a: 162; Graells, 2007: 95). En sociedades jerarquizadas como la celtibérica o la ibérica, donde el gobierno de las comunidades lo ejercía una élite aristocrática de marcado carácter militar, la espada era un indicador del estatus de su propietario y de su pertenencia a esa élite.

La trascendencia del armamento en general y, de un modo más específico, de las espadas, se manifiesta en su uso ceremonial y ritual. Los guerreros despojaban de sus armas a los enemigos vencidos en el campo de batalla (spolio hostium) y posteriormente las utilizaban en ritos iniciáticos o las ofrecían a los dioses depositándolas en lugares de culto (santuarios, lagos, ríos, etc.), en las puertas de acceso a la ciudad o en sus propias casas (Gabaldón, 2004: 24-25). El carácter sagrado de las espadas también justifica su amortización en las tumbas, al tratarse de elementos que desempeñaban un papel activo y destacado en la heroización del guerrero (Guaitoli, 2004: 26; Graells, 2007: 95). Asimismo, a determinados modelos de espadas, como es el caso de las falcatas, se les atribuyen funciones sacrificiales y se relacionan con los banquetes funerarios (Quesada, 1997a: 167). En este sentido, conviene señalar que en la e. f. 11 de El Castillo, además de la falcata (11.9), se recuperaron un número elevado de utensilios metálicos relacionados con ritos de sacrificio y banquete (Faro, 2015: 101-104). Entre ellos una azuela (11.48) y un hacha martillo o hacha de doble filo (11.62), herramientas que pudieron haber sido utilizadas de forma conjunta con la falcata durante el proceso de ejecución de los animales sacrificados.

En la necrópolis de El Castillo, el registro arqueológico de las tumbas de guerreros correspondiente a la Fase III ( $2^{\mathrm{a}} 1 / 2 \mathrm{~s}$. IV - s. III a. C. ) también demuestra que, en el desarrollo de los diferentes actos que formaban parte de los funerales de estos personajes, las armas ocuparon un lugar preferente. Un claro ejemplo de esta realidad es la manipulación intencionada y ritual de cuatro espadas $(23.6,44.11,141.10$ y 167.7) de forma previa a la cremación del individuo y a su destino final en la sepultura. Esta manipulación tenía como propósito adaptar las dimensiones de los objetos al lugar elegido para su depósito definitivo en la tumba, en estos casos en el interior de un pequeño rebaje o loculus. 
Las espadas recuperadas en El Castillo, a diferencia del patrón más repetido en las necrópolis ibéricas en el periodo comprendido entre los s. IV y III a. C. (Quesada, 1997a: 645), no aparecen como única arma, exceptuando el ejemplar 137.9. Formaban parte de panoplias complejas, con armas tanto ofensivas como defensivas. Las piezas que se asocian con más frecuencia a las espadas son los escudos de tipo caetra, los soliferrea y las lanzas. La combinación de estos cuatro elementos se registra en las e. f. 23 y 44. En la e. f. 141 está ausente la punta de lanza, aunque cabe la posibilidad de que se encuentre depositada dentro del casco, junto a la espada de La Tène. En las e. f. 11 y 167 no incluyeron el soliferreum. Este tipo de enterramientos pertenecen, por tanto, a la etapa que F. Quesada denominó como fase plena o de panoplia generalizada, que abarca desde comienzos o desde el segundo cuarto del s. IV a. C. hasta el último tercio del s. III a. C., coincidiendo con la Segunda Guerra Púnica (Quesada, 1997a: 611-615; 2002: 42-49).

En lo que hace referencia a otros objetos, resulta muy significativa su relación con utensilios metálicos relacionados con rituales de sacrificio y banquete, que están presente en las e. f. 11, 23 y 141 (Faro, 2015). Asimismo, también se han vinculado a grapas y/o charnelas de diphroi en la e. f. 11 y 167, que son indicativas del uso para el traslado del difunto a la necrópolis de un carro y de un lecho móvil, respectivamente. Entre los objetos de indumentaria y de adorno, cabe señalar la asociación con fíbulas de La Tène con apéndice caudal zoomorfo del tipo 8A3 de Argente, en todas las sepulturas con espadas, a excepción de la e. f. 23.

Por último, en lo que respecta a los servicios cerámicos, al margen de las grandes copas de perfil crateriforme utilizas como urna en las e. f. 11 y 141, también se documenta un modelo de copa de perfil caliciforme continuo en "S" o carenado. Los ejemplares hallados en las e. f. 23, 44, 137 y 167 presentan decoraciones sencillas con incisiones a peine y/o cordones aplicados cerca del borde. Por su parte, los fragmentos de las catalogadas en la e. f. 11 presentan motivos decorativos en los que se combinan distintas técnicas (aplicada, impresa e incisa a peine), que dan lugar a composiciones complejas con un elevado grado de barroquismo (Faro, 2015: 41, fig. 25).

Las espadas analizadas corresponden en su totalidad a tumbas de la Fase III ( $2^{\mathrm{a}} 1 / 2 \mathrm{~s}$. IV - s. III a. C.). Atendiendo a sus características técnicas y morfológicas, los ejemplares de antenas (23.6 y 44.11) pueden fecharse en los s. V - IV a. C. y los ejemplares de La Tène y la falcata entre finales del s. IV a. C. y el s. III a. C.

Los enterramientos excavados en la necrópolis de El Castillo demuestran que desde fechas tempranas, al menos desde el s. VI a. C., en este territorio se configuraron sociedades complejas y estratificadas. Así se deduce de la disparidad registrada en el tamaño de los túmulos y en los ajuares depositados en las tumbas de la Fase I ( $2^{\mathrm{a}} 1 / 2 \mathrm{~s}$. VI - inicios s. V a. C.). También se ha podido constatar que, en esta etapa, la clase dirigente ya tenía acceso a bienes considerados de lujo y prestigio (Faro, 2015: 37-38).

A lo largo del s. V a. C., en todo el territorio peninsular, se produjo una profunda transformación vinculada al ascenso de nuevas élites aristocráticas de índole guerrera que asumieron el control del poder, de las fuerzas productivas, de los excedentes alimentarios y de las rutas comerciales. Las necrópolis del extremo occidental del valle medio del Ebro constituyen un testimonio excepcional de estos cambios. En los enterramientos fechados a partir de la Fase II ( $2^{\mathrm{a}} 1 / 2 \mathrm{~s}$. V $-1^{\mathrm{a}} 1 / 2 \mathrm{~s}$. IV a. C.), se ha documentado la presencia de armas tanto en El Castillo (Faro, 2015: 38-40) como en La Atalaya (Cortes, Navarra) (Castiella, 2005: 194-198, figs. 109-111). Armas que no se habían registrado en la etapa precedente y que, a partir de este momento, jugaron un papel muy destacado en los ritos funerarios, no solo como indicadores de prestigio y riqueza, sino como expresión de poder y demostración de jerarquía. Este proceso culminó hacia mediados del s. IV a. C., a partir de este momento se detecta un incremento con- 
siderable en el número de sepulturas con armas y comienzan a registrarse tumbas de guerreros con panoplias complejas. Los enterramientos 11, 13, 23, 30, 36, 44, 141 y 167 de la Fase III (2 ${ }^{\mathrm{a}}$ $1 / 2$ s. IV - s. III a. C.) de El Castillo son el mejor exponente de esta realidad. Los clanes dirigentes llegaron a acumular una gran cantidad de bienes de prestigio que, en un acto de ostentación pública y de reafirmación de poder, eran utilizados y exhibidos durante los distintos actos del funeral, para finalmente acabar depositados en las piras y amortizados en las tumbas. En este nuevo orden social, la espada se convirtió en un elemento distintivo de la élite guerrera.

\section{BIBLIOGRAFÍA}

Almagro-Gorbea, M. (1997): «Guerra y sociedad en la Hispania céltica», J. A. García Castro y V. Antona (coords.), La guerra en la antigüedad. Una aproximación al origen de los ejércitos en Hispania (Exposición, Madrid 29 de abril-29 de junio 1997). Madrid, Fundación Caja de Madrid: 207-221.

Almagro-Gorbea, M. y Lorrio, A. (2011): Teutates: el héroe fundador y el culto al antepasado en Hispania y la Keltiké. Bibliotheca Archaeologica Hispana, 36. Madrid, Real Academia de la Historia.

Argente, J. L. (1994): Las fibulas de la Edad del Hierro en la Meseta Oriental: valoración tipológica, cronológica y cultural. Madrid, Ministerio de Cultura.

Barril, M. (2004): «Espada de tipo Echauri», Catálogo de la exposición: La herencia del pasado (II). Últimas adquisiciones del Museo Arqueológico Nacional (2002-2003). Madrid, Museo Arqueológico Nacional: 23-24.

Bona, I. J., Borque, J. J., Giner, E., Alcalde, M., Bernal, A. y Escribano, J. C. (1983): «Catálogo de la colección arqueológica del Monasterio de Veruela». Turiaso, 4: 9-92.

Bosch Gimpera, P. (1921): «Los celtas y la civilización céltica en la Península Ibérica». Boletín de la Sociedad Española de Excursionistas, 29 (4): 248-301.

Burillo, F. (1977): «Materiales de la Primera Edad del Hierro aparecidos en El Busal (Uncastillo, Zaragoza)». Estudios del Seminario de Prehistoria, Arqueología e Historia Antigua, 3: 51-67.

Cabré de Morán, M. ${ }^{a}$ E. (1956): «Notable espada de antenas de La Osera», IV Congreso Internacional de Ciencias Prehistóricas y Protohistóricas, Madrid. Zaragoza, Librería General: 753-758.

Cabré de Morán, M. ${ }^{a}$ E. (1990): «Espadas y puñales de las necrópolis celtibéricas», F. Burillo (coord.), Necrópolis Celtibéricas. II Simposio sobre los Celtíberos (1988, Daroca, Zaragoza). Zaragoza, Institución Fernando el Católico: 205-224.

Castiella, A. (2005): «Sobre los ajuares de la necrópolis de La Atalaya. Cortes, Navarra». Cuadernos de Arqueología de la Universidad de Navarra, 13: 115-210.

Castiella, C. (2007): «El poblado y la necrópolis de la I Edad del Hierro en Valtierra (Navarra)». Cuadernos de Arqueología de la Universidad de Navarra, 15: 193-243.

Castiella, C. y Bienes, J. J. (2002): «La vida y la muerte durante la protohistoria en El Castejón de Arguedas (Navarra)». Cuadernos de Arqueología de la Universidad de Navarra, 10: 7-211.

Castiella, C. y Sesma, J. (1988-1989): «Piezas metálicas de la Protohistoria. Navarra: armas”. Zephyrvs, 41: 383-404.

Cerdeño, M. ${ }^{a}$ L. (1978): «Los broches de cinturón peninsulares de tipo céltico». Trabajos de Prehistoria, 35 (1): 279-307.

Cuadrado, E. (1987): La necrópolis ibérica de El Cigarralejo. Bibliotheca Praehistorica Hispana. Madrid, CSIC.

Cuadrado, E. (1989): La panoplia ibérica de El Cigarralejo (Mula, Murcia). Murcia, Servicio Regional de Patrimonio Histórico.

Faro, J. A. (2002): «Protohistoria», A. García Paredes (coord.), Castejón, cuatro milenios de Historia. Castejón, Ayuntamiento de Castejón: 28-38.

Faro, J. A. (2015): «La necrópolis de El Castillo (Castejón, Navarra). Vajilla e instrumental metálico de sacrificio y banquete en el valle medio del Ebro (s. VI - III a. C.)». Lvcentvm, 34: 31-118. https:// doi.org/10.14198/lvcentvm2015.34.03

Faro, J. A. (2016): Ritos funerarios en el valle medio del Ebro (s. VI - III a. C.). Necrópolis de El Castillo (Castejón, Navarra). Tesis doctoral, 3 vols. UNED. 
Faro, J. A. (2017): «Las lúnulas de la necrópolis de la Edad del Hierro de El Castillo (Castejón, Navarra)». Archivo Español de Arqueología, 90: 171-193. http://dx.doi/10.3989/aespa.090.017.008

Faro, J. A., Cañada, F. y Unzu, M. (2002-2003): «Necrópolis de El Castillo (Castejón. Navarra). Primeras valoraciones, campañas 2000-2001-2002». Trabajos de Arqueología Navarra, 16: 45-77.

Faro, J. A. y Unzu, M. (2006): «La necrópolis de la Edad del Hierro de El Castillo (Castejón. Navarra). Primeras valoraciones: campañas 2000-2002». Complutum, 17: 145-166.

Floristán, A. (1995): Geografia de Navarra. Pamplona, Diario de Navarra.

Gabaldón, M ${ }^{\mathrm{a}}$ M. (2004): Ritos de armas en la Edad del Hierro: armamento y lugares de culto en el antiguo Mediterráneo y el mundo celta. Anejos de Gladius, 7. Madrid, CSIC.

García Jiménez, G. (2006): «Las primeras producciones de antenas de la Meseta. Patrones de influencia y desarrollo morfológico de las espadas de tipo Echauri/Quesada II». Gladius, 26 (1): 19-60. https:// doi.org/10.3989/gladius.2006.2

García Jiménez, G. (2011): El armamento de influencia La Tène en la Península Ibérica (siglos V-I a. C.). Tesis doctoral. Universitat de Girona.

Graells, R. (2007): «¿Culto heroico durante la primera edad del Hierro e Ibérico antiguo en el noreste peninsular? Algunas consideraciones a partir del registro funerario». Cuadernos de Prehistoria y Arqueología, 33: 91-115. https://doi.org/10.15366/cupauam2007.33.005

Graells, R. (2008a): Análisis de las manifestaciones funerarias en Catalunya durante los ss. VII y VI a. C. Sociedad y cultura material: la asimilación de estímulos mediterráneos. Tesis doctoral. Universitat de Lleida.

Graells, R. (2008b): «Mistophoroi ilergetes en el siglo IV AC: el ejemplo de las tumbas de caballo de la necrópolis de la Pedrera (Vallfogona de Balaguer-Térmens, Catalunya, España)». Jahrbuch des Römisch-Germanischen Zentralmuseums Mainz, 55: 81-158.

Graells, R., Lorrio, A. y Quesada, F. (2014): Cascos hispano-calcídicos. Símbolos de las élites guerreras celtibéricas. Kataloge Vor-und Frühgeschichtlicher Altertümer, 46. Mainz, Römisch-Germa nischen Zentralmuseums Mainz.

Guaitoli, M. T. (2004): «La dimensione di guerriero, príncipe ed eroe atraverso le fonti letterari e le testimonianze archeologiche», F. Marzatico y P. Gleirscher (eds.), Gerrieri, principie ed eroi fra il Danubio e il Po, dalla preistoira all'alto medioevo. Trento, Provincia Autonoma di Trento: 17-34.

Iriarte, A., García-García, M. ${ }^{a}$ L., Filloy, I., Gil, E. y Sesma, J. (1996): "El depósito de armas de La Azucarera (Alfaro, La Rioja)». Cuadernos de Arqueología de la Universidad de Navarra, 4: 173-194.

Jacobsthal, P. (1969): Early Celtic Art. Oxford, Oxford University Press: II vols.

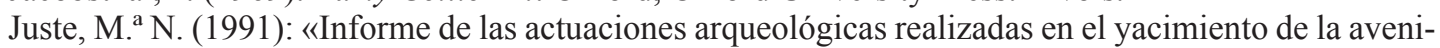
da Martínez de Velasco, Huesca: 1988 y 1989», J. I. Royo y J. L. Acín (coords.), Arqueología Aragonesa, 17. Zaragoza, Diputación General de Aragón: 365-370.

Landry, C. y Blaizot, F. (2011): «Une sépulture de guerrier celte à Chens-sur-Léman (Haute-Savoie)». Revue archéologique de l'Est, 60: 147-171.

Lejars, T. (2003): «Les forreaux d'épée laténiens. Supports et ornamentations», D. Vitali (ed.): L'immagine tra mondo celtico e mondo etrusco-italico: aspetti della cultura figurativa nell'antichità. Florencia, Gedit: 9-70.

Llanos, A. (1990): «Necrópolis del Alto Ebro», F. Burillo (coord.), Necrópolis Celtibéricas, II Simposio sobre los Celtíberos (1988, Daroca, Zaragoza). Zaragoza, Institución Fernando el Católico: 137147.

Lorrio, A. J. (1997): Los Celtíberos. Alicante, Universidad de Alicante.

Lorrio, A. J. y Sánchez de Prado, M. ${ }^{a}$ D. (2009): La necrópolis celtibérica de Arcóbriga (Monreal de Ariza, Zaragoza). Zaragoza, Institución Fernando el Católico.

Maluquer, J. (1953): «La necrópolis de la Edad del Hierro de La Torraza, en Valtierra (Navarra)». Príncipe de Viana, 14: 243-269.

Maluquer, J. y Vázquez de Parga, L. (1956): «Avance del estudio de la necrópolis de La Atalaya, Cortes de Navarra». Príncipe de Viana, 17: 389-454.

Mohen, J. P. (1980): L'age du fer en Aquitaine. París, Société Préhistorique Française.

Negueruela, I. (1990): Los monumentos escultóricos Ibéricos del Cerrillo Blanco de Porcuna (Jaén): estudio sobre su estructura interna, agrupamientos e interpretación. Madrid, Ministerio de Cultura.

Olcoz, I. (2011): «Nueva falcata ibérica en Navarra». Príncipe de Viana, 253: 63-67. 
Oliver, A. (2012): «Los iberos en un territorio de encrucijada», M. ${ }^{a}$ C. Belarte, J. A. Benavente, L. Fatás, J. Diloli, P. Moret y J. Noguera (eds.), Iberos del Ebro. Actas del II Congreso Internacional (Alcañiz-Tivissa, 16-19 de noviembre de 2011). Documenta, 25. Tarragona, Institut Catalá d'Arqueologia Clàssica.

Pelegrín, J. (2003): Barbarie y Frontera: Roma y el Valle medio del Ebro durante los siglos III - I a. C. Tesis doctoral. Universidad de Zaragoza.

Pilloy, J. (1899): Les tertres funéraires d'Avezac-Prat. Paris, Libraires de L'Académie de Médicine.

Quesada, F. (1997a): El armamento ibérico. Estudio tipológico, geográfico, funcional, social y simbólico de las armas en la Cultura Ibérica (siglos VI-I a. C.). Monographies Instrumentum, 3. Montagnac, Monique Mergoil.

Quesada, F. (1997b): «Algo más que un tipo de espada: la falcata ibérica», J. A. García Castro, y V. Antona (coords.), La guerra en la antigüedad. Una aproximación al origen de los ejércitos en Hispania (Exposición, Madrid 29 de abril-29 de junio 1997). Madrid, Fundación Caja de Madrid: 196-205.

Quesada, F (2002): «La evolución de la panoplia. Modos de combate y tácticas de los iberos», P. Moret y F. Quesada (coords.), La guerra en el mundo ibérico y celtibérico (ss. VI - II a. C.). Madrid, Casa Velázquez: 35-64.

Quesada, F. (2005): «El gobierno del caballo montado en la Antigüedad clásica con especial referencia al caso de Iberia. Bocados, espuelas y la cuestión de la silla de montar, estribos y herraduras». Gladius, 25 (1): 97-150. https://doi.org/10.3989/gladius.2005.26

Rapin, A. (1989): «L'épée et le fourreau de la sépulture 13 de la nécropole de Mainville" à Bromeilles (Loiret)». Revue archéologique du Centre de la France, 28 (1): 7-14.

Rapin, A. (1999): «L'armement celtique en Europe: cronologie de son evolution technologique du Ve au Ie J.-C. ». Gladius, 19 (1): 36-68. https://doi.org/10.3989/gladius.1999.13

Romero, F.; Sanz Mínguez, C. y Górriz, C. (2009): «El vino entre las élites vacceas. De los más antiguos testimonios a la consolidación de su consumo», C. Sanz Mínguez y F. Romero (eds.), El vino y el banquete en la Europa prerromana. Valladolid, Centro de Estudios Vacceos "Federico Wattenberg" de la Universidad de Valladolid: 225-251.

Royo, J. I. (1980): «Hallazgos metalúrgicos de la I ${ }^{a}$ Edad del Hierro en Aragón. Aproximación al estudio de la metalurgia en nuestra región durante la etapa hallsttática». Turiaso, 1: 241-324.

Ruiz Zapatero, G. (1985): Los Campos de Urnas del N.E. de la Península Ibérica. Tesis Doctoral. Universidad Complutense de Madrid.

Sanz Mínguez, C. (1997): Los Vacceos: cultura y ritos funerarios de un pueblo prerromano del valle medio del Duero. La necrópolis de Las Ruedas, Padilla de Duero (Valladolid). Salamanca, Junta de Castilla y León.

Schüle, W. (1969): Die Mesesta Kulturen der Ibersichen Halbinsel, 2 vol. Berlin.

Stead, I. M. y Rigby, V. (1999): The Morel Collection: Iron Age. London, British Museum.

Szabo, M. (1996): «L'expansion celte et l'armement décoré». Mélanges de l'Ecole française de Rome. Antiquité, 108 (2): 523-553.

Recibido: 14-04-2016

Aceptado: 27-02-2017 